\title{
Intertidal Zonation of Marine Algae at Gloucester Point, Virginia
}

\author{
Barry Lee Wulff \\ College of William and Mary - Virginia Institute of Marine Science
}

Follow this and additional works at: https://scholarworks.wm.edu/etd

Part of the Marine Biology Commons, and the Oceanography Commons

\section{Recommended Citation}

Wulff, Barry Lee, "Intertidal Zonation of Marine Algae at Gloucester Point, Virginia" (1967). Dissertations, Theses, and Masters Projects. Paper 1539617398.

https://dx.doi.org/doi:10.25773/v5-a02z-4c62

This Thesis is brought to you for free and open access by the Theses, Dissertations, \& Master Projects at W\&M ScholarWorks. It has been accepted for inclusion in Dissertations, Theses, and Masters Projects by an authorized administrator of W\&M ScholarWorks. For more information, please contact scholarworks@wm.edu. 


\title{
INTERTIDAL ZONATION OF MARINE ALGAE \\ AT GLOUCESTER POINT, VIRGINIA
}

\author{
A Thesis
}

Presented to

The Faculty of the Department of Marine Science The College of William and Mary in Virginia

\author{
In Partial Fulfillment \\ of the Requirements for the Degree of \\ Master of Arts
}

By

Barry L. Wulfe

1967 
APPROVAL SHEET

This thesis is submitted in partial fulfillment of the requirements for the degree of Mister of Arts

BangyL.Wueff

Approved, November, 1967

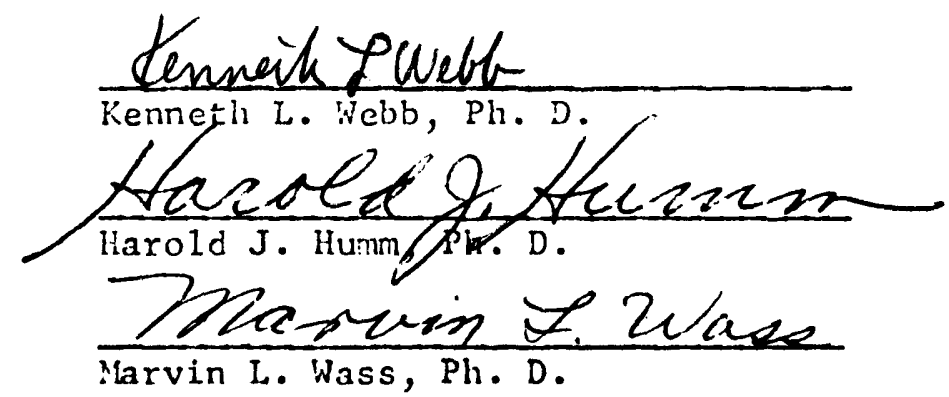

ii 


\section{AC KNOWLEDGMENTS}

Appreciation is extended to $\mathrm{Dr}$. Kenneth L. Webb, of the Virginia Institute of Marine Science, for support, guidance and assistance received throughout the pursuit of this study. I also wish to thank Dr. Harold J. Humm of the Marine Science Center of the University of South Florida, St. Petersburg, for inspiration and encouragement in this study. I am obliged to Dr. Francis Drouet of the Philadelphia Academy of Natural Sciences, who confirmed and provided determinations for several specimens of Cyanophyta. I am also grateful to Dr. E. Conway of the University of Glasgow, Scotland, for the determination of Porphyra uribilicalis. To my colleagues, Messers. Bruce Robison, William DuPaul and Michael O'Brien, I give sincere appreciation for their assistance during preparatory work and in making collections.

I am further indebted to my wife, Ella May, who provided constant encouragement during the course of this study and assisted in preparation of the manuscript. 
TABLE OF CONTENTS

Page

ACKNOWLEDGMENTS $\ldots \ldots \ldots \ldots \ldots \ldots \ldots \ldots \ldots \ldots \ldots \ldots \ldots \ldots \ldots \ldots \ldots$

LIST OF TABLES $\ldots \ldots \ldots \ldots \ldots \ldots \ldots \ldots \ldots \ldots \ldots \ldots \ldots \ldots \ldots \ldots$

LIST OF FIGURES $\ldots \ldots \ldots \ldots \ldots \ldots \ldots \ldots \ldots \ldots \ldots \ldots \ldots \ldots \ldots \ldots \ldots$

ABSTRACT $\ldots \ldots \ldots \ldots \ldots \ldots \ldots \ldots \ldots \ldots \ldots \ldots \ldots \ldots \ldots \ldots \ldots \ldots \ldots$

INTRODUCTION $\ldots \ldots \ldots \ldots \ldots \ldots \ldots \ldots \ldots \ldots \ldots \ldots \ldots \ldots \ldots \ldots \ldots \ldots$

REVIEW OF RELATED LITERATURE $\ldots \ldots \ldots \ldots \ldots \ldots \ldots \ldots \ldots \ldots \ldots \ldots$

METHODS AND MATERIALS $\ldots \ldots \ldots \ldots \ldots \ldots \ldots \ldots \ldots \ldots \ldots \ldots . \ldots \ldots$

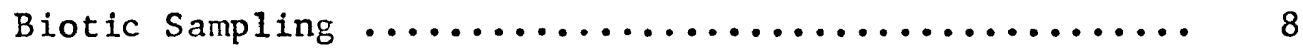

Measurement of Physical and Chemical Factors ........ 10

Statistical Analysis $\ldots \ldots \ldots \ldots \ldots \ldots \ldots \ldots \ldots \ldots \ldots \ldots . \ldots 11$

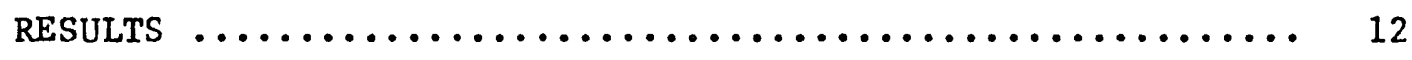

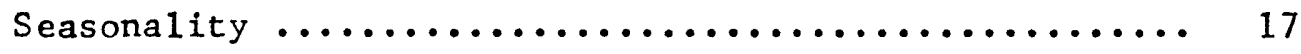

Colonization and succession $\ldots \ldots \ldots \ldots \ldots \ldots \ldots \ldots . \ldots \ldots$

Intertidal Zonation $\ldots \ldots \ldots \ldots \ldots \ldots \ldots \ldots \ldots \ldots \ldots \ldots$

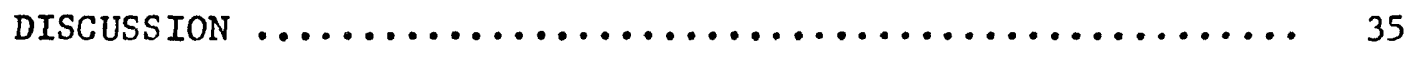

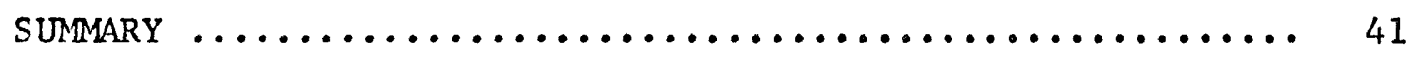

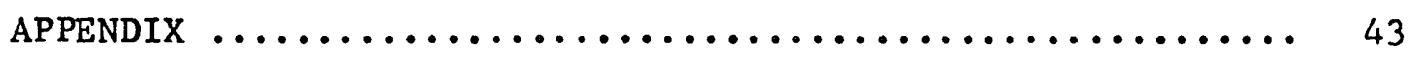

LITERATURE CITED $\ldots \ldots \ldots \ldots \ldots \ldots \ldots \ldots \ldots \ldots \ldots \ldots \ldots \ldots \ldots \ldots$ 


\section{LIST OF TABLES}

Number

II

Record of occurrence of algae collected from

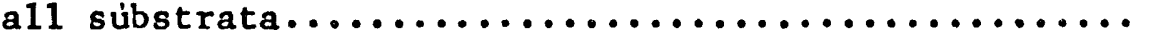

Page

13

18 


\section{LIST OF FIGURES}

Number

Title

Page

1. Chart of Tidewater Virginia showing collection area in lower York River adjacent to the Virginia Institute of Marine Science at Gloucester Point, Virginia... 4

2. Temporary collector with acrylic plastic substrata.... 9

3. Average monthly salinity (ppt) from January, 1966 to June, 1967 at the collection area.............. 14

4. Daily range of water temperature $\left({ }^{\circ} \mathrm{C}\right)$ from January to June, 1967 at Gloucester Point, Virginia......... 15

5. Average daily air temperature $\left({ }^{\circ} \mathrm{C}\right)$ from January to June, 1967 at Gloucester Point, Virginia.......... 16

6. Intertidal zonation on succession substrata, June 1...20

7. Intertidal zonation on colonization substrata,

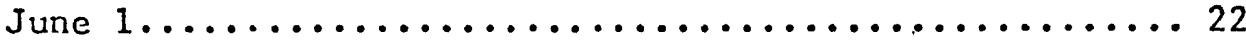

8. Intertidal zonation on colonization substrata,

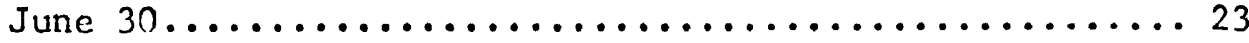

9. Intertidal zonation on succession substrata, June $30 \ldots 24$

10. Intertidal zonation on the permanent substratum,

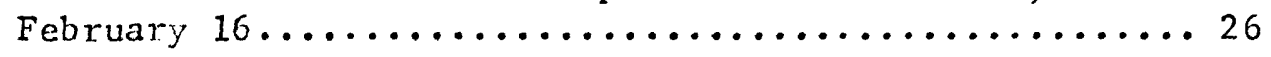

11. Intertidal zonation on the permanent substratum,

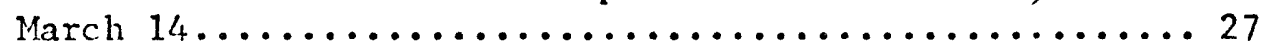

12. Intertidal zonation on the permanent substraturn,

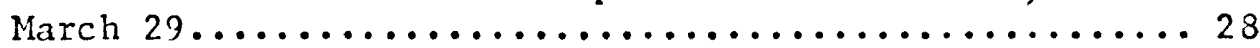

13. Intertidal zonation on the permanent substratun,

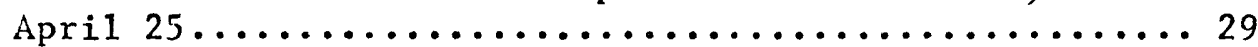

14. Intertidal zonation on the permanent substratum,

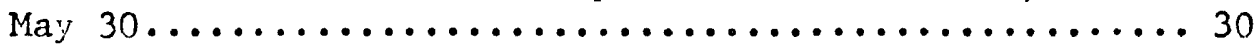

15. Intertidal zonation on the permanent substratum,

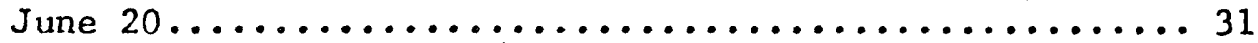

16. A summary of the zonation of intertidal flora....... 32

17. Jaccard's coefficients of similarity for all cm

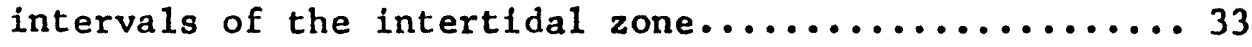


A study was made of the interticial zone rif aged weoden pilings from February to June, 1967 at Gloucester Point Virginia, located in the lowey youl piver estuary. Twenty-six species of maxine algae were found grouper into three floristic zones.

Nine species were linited to: below mean low watcr, wialis dalinited the lowest nons. In this group there were six Rhodophyta anc three Chlorophyta. Seven floral levels compised tlic r. fidle floristic zone between mean low water to a height of $74 \mathrm{~cm}$ above mean low water. These $3 \in \mathrm{v} \in \mathrm{l}$ s cre based on uppermost range extensions of sixteen specics (six Cyanophyta, two Rhodophyta, one Phaeophyta and seven Chlorophyta). The Cyanophyta Calothrix crustacea formed the highest floristic zone attaining a maximum height of $122 \mathrm{~cm}$ above mean low water.

Collections from acrylic plastic plates showed a change in the floral ccrposition below mean low water during May and June.

Six species were found during the study period that were previcusly unreported from Virginia: Ectocarpus conferyoides Enteromorpha compressa, Enteromorpha erecta, Enteromorpha prolifera Monostroma leptodermum and Ulothrix flacca. 


\section{INTRODUCTION}

Study of the ecology and distribution of benthic marine algae along the coasts of Delaware, Maryland and Virginia, including Chesapeake Bay and its estuaries, has been sadly neglected. Only recently have studies been initiated on the marine algae in this region. Zaneveld and Barnes (1965) elucidated the seasonal periodicity of some marine algae in lower Chesapeake Bay. The Cyanophyta from Cape May, New Jersey to Cape Hatteras, North Carolina have been described (Zaneveld, 1966), and a preliminary survey of the marine algae of Delaware has been completed (Zaneveld, 1966b).

The first significant study of intertidal zonation of marine algae on the Atlantic coast of North America was by Johnson and Skutch (1928) at Mt. Desert Island, Maine. T. A. Stephenson and A. Stephenson surveyed the intertidal fauna and flora of the Florida Keys (1950), northern Florida to the Carolinas (1952) and Nova Scotia and Prince Edward Island (1954). Kingsbury (1962), in determining the effects of wave-action on the composition of an algal population on a rock jetty at the entrance to West Falmouth Harbor, Massachusetts, described vertical limits for a large number of intertidal algae. Recently Earle and Humm (1964) completed a study of the summer marine flora inhabiting various intertidal substrata in Beaufort Harbor, North Carolina.

The horizontal and vertical distribution of marine flora in estuarine conditions is poorly known. The local environment 
provided an opportunity to study the vertical distribution of benthic marine algae in an estuarine environment. The present work describes the upper vertical linits of marine algae (Cyanophyta, Rhodophyta, Chlorophyta and $[1:$ copllyte) found during the monthe February to June, 1967, in the lower York River estuary (Fig. 1) adjacent to the Virginia Institute of Marine Science (VIMS). Observations on colonization and succession of some species are presented and the relationship of environmental parameters to the presence and distribution of species is discussed. 


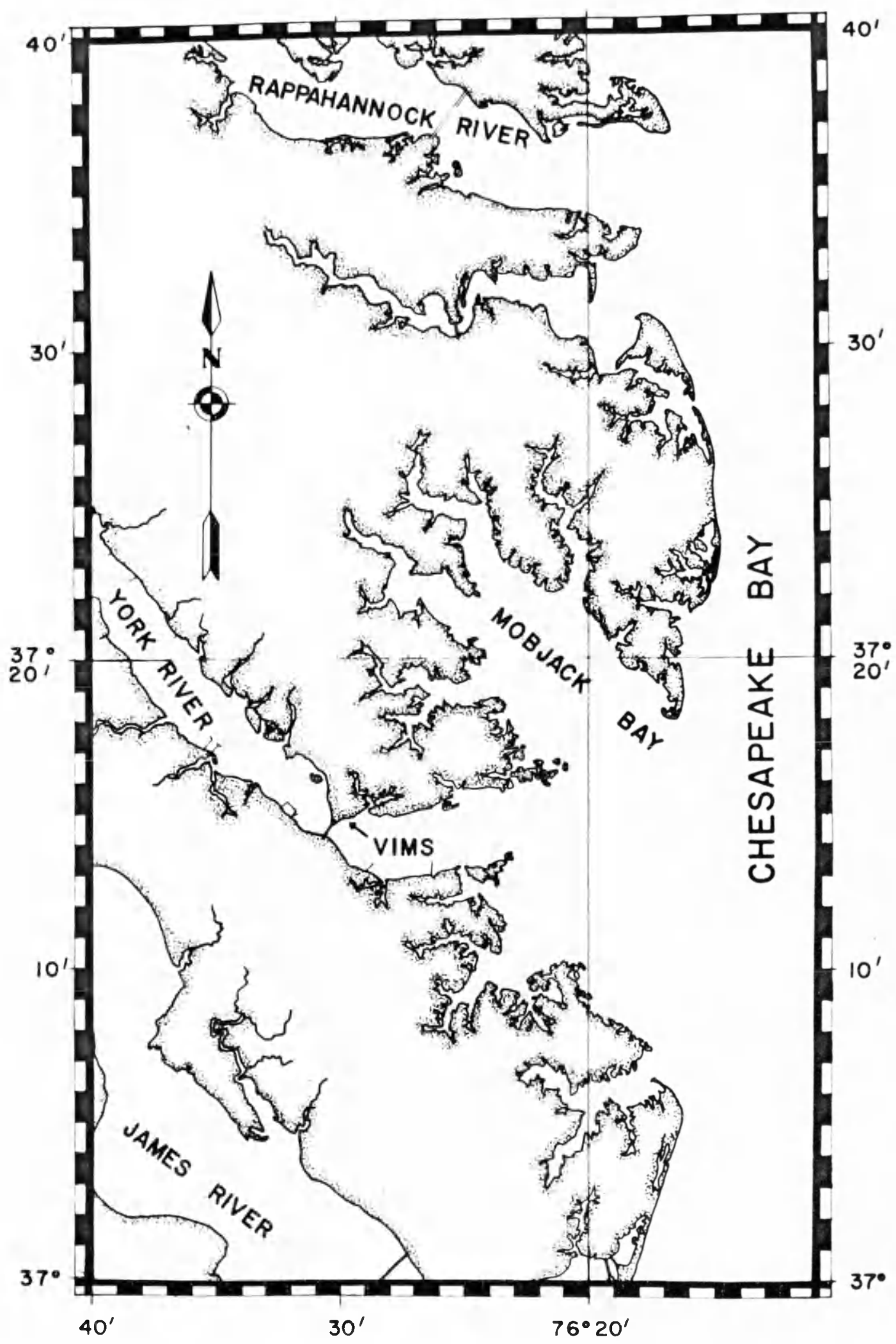

Fig. 1. Chart of Tidewater Virginia showing collection area in lower York River adjacent to the Virginia Institute of Marine Science at Gloucester Point, Virginia. 


\section{REVIEW OF RELATED LITERATURE}

Intertidal zonation has intrigued investigators for many years and numerous attempts have been made to delimit universally recognizable intertidal zones. The precise limits of these zones, terminology and aharacterizing criteria vary greatly among authors (Doty, 1957). Descriptions based solely on the position of prominent or abundant intertidal organisms are adequate only in the area investigated; the vertical range of a species may differ throughout its horizontal distribution. Also some species are seasonal entities and most studies are insufficient for delimiting a global zonation scheme because tides are peculiar to each location; classifications employing numbers or letters have similarly failed.

The proposed classifications of intertidal areas have been excellently reviewed and analyzed by Doty (1957). The most widely used system in existence today is that of T. A. Stephenson and A. Stephenson (1949). They divided the share into three basic regions: the supralittoral fringe, midlittoral and infralittoral fringe. The supralittoral fringe extends from the upper limit of littorinids, which is slightly above extreme high water springs (E.H.W.S.) to the upper limit of barnacles just below extreme high water neaps (E.H.W.N.). In this area, not wetted by every high tide, Cyanophyta, and in particular Calothrix, are usually abundant. The midlittoral zone is situated between the supra- and infra-littoral fringes and is alter- 
nately submerged and exposed by every tidal cycle. The infralittoral fringe extends from the lower limit of barnacles, at extreme low water neaps (E.I.W.Ni.) bordering on laminarians (sometimes replaced by Rhodophyta), down to approximately extreme low water springs (E.L.W.S.). Despite objections to the system (e.g•, Womersley and Edmonds, 1952), flexibility has ensured its wide acceptance.

Several environmental factors exert different degrees of influence on each species inhabiting intertidal areas (Colman, 1933; Doty, 1957; Southward, 1958; Lewis, 1964). Tides essentially contro1 the vertical distribution of intertidal organisms in the marine enviranment. Tidal amplitude is the primary factor determining the height of intertidal faunal and floral assemblages. In areas of extremely great tidal amplitude tic verticol wicths of floral zones are expanded with only limited control by wave-action; in areas with a reduced tidal range, certain zones may be eliminated and the assemblages governed by other variations, such as waves.

Doty (1946) recognized six intertidal zones along the Oregon and Califomia coasts and related each to a critical ticil icvel. Ite concept of critical tide levels, first introcirced by Colnan (1933), presupposes that intertidal organisms have a certain toleranc Ifmit to atmospheric expcsure and submergence bereath the water. Few studies on intertidal zonation have been related to precise tidal heights because of a lack of adequate reference points and concurrent tidal measurements. Wave-beaten shores are generally more complex, often showing less clearly defined zones. The amount, type and strength of waves must be considered. Southward (1958) stated two ways in which waves may Influence zonation: (1) wetting by waves or splash of suffictent 
height or frequency may act simflarly to tides and (2) meohanical action due to wave energy may promote or discourage growth of certain organisms. Instruments for measuring intensity of waves have not been thoroughly utilized. Johnson and skutch (1928) found the upper limit of the intertidal zone elevated two feet or more (due to wave-action) on the open ocean side of Mt. Desert Island, Maine over that in nearby quieter waters. Kingsbury (1962) and Southward and Orton (1954) found increased complexity and a greater number of species on the wave-beaten sides of jetties: Doty (1946) stated that wetting by waves every few seconds is comparable to constant submergence.

Semidiurnal tides are characteristic of the Western Atlantic; twice daily the intertidal zone is exposed to the atmosphere and submerged beneath the water. While out of water, algae are subjected to osmotic stress modified by desiccation and rain. The physiological adaptations by intertidal algae to desiccation, osmotic changes, temperature and light are reviewed by Bieb1 (1962).

In temperate latitudes blue-green algae are conspicuous members of the intertidal zone. Drouet and Daily (1956) and Drouet (1962, 1963, 1964) stated that different environmental conditions promote ecological growth forms (ecophenes) of many Cyanophyta. On this basis Drouet (personal communication) is presently revising the classification of the Oscillatoriaceae, which will significantly reduce the number of genera and species in this group. 
METHODS AND MATERIALS

\section{B lotic Sampling}

To determine intertidal zonation, systematic, qualitative collections were made from aged wooden pllings at the end of the old ferry pier at Gloucester Point, Virginia. These pilings were selected because their flora is probably most representative of the local intertidal zonation and they present a continuous surface throughout the intertidal zone. In January a metric rule was attached to the south facing side of selected pilings and at least once each month during the spring all material from a strip $8 \mathrm{~cm}$ wide, from about $38 \mathrm{~cm}$ below mean low water (MLW) to about $140 \mathrm{~cm}$ above $M L W$, was removed in $4 \mathrm{~cm}$ segments and placed in 4 oz jars containing $5 \%$ seawater formalin. Each month a new surface was sampled.

To determine colonization and succession, two temporary substrata, each consisting of a series of $4 \times 8 \mathrm{~cm}$ roughened acrylic plastic plates, were juxtaposed in a holder and oriented in a vertical plane (Fig. 2). A $4 \mathrm{~cm}$ interval rule was painted on the holder for orientation, and the collector was designed so that it could be removed from the water periodically in order for subtidal sampling to be ac omplished.

A11 acrylic plastic plates were inspected monthly. From one series of plates a record of the species present was made, the plates were completely cleaned and returned to the holder. The data provided an indication of which species had colonized the substrata during the 

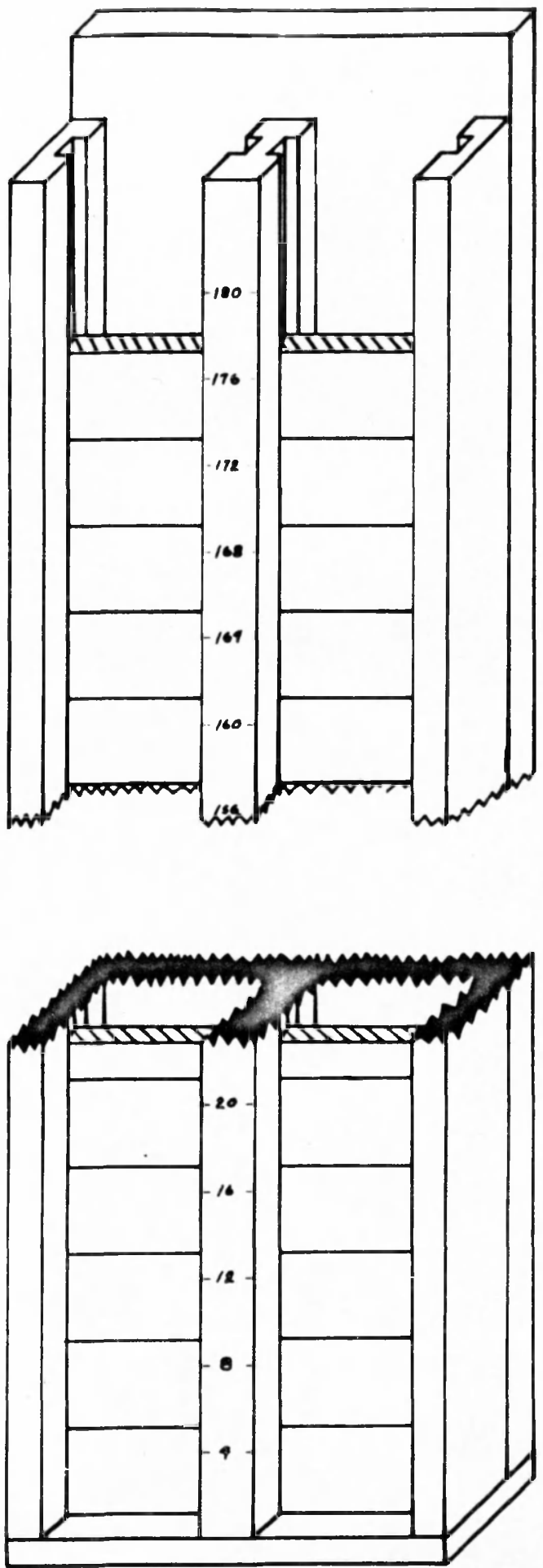

Fig. 2. Temporary collector with acrylic plastic substrata. 
previous month. From the second series of plates, the algae were identified and the plates returned intact to their normal sequence in the holder without removal of any material. This provided information on algal succession. Names for the Oscillatoriaceae (Cyanophyta) identified in the collections are based upon a revised system of classification (Francis Drouet, personal communication). Of the Cyanophyta found in this study, Drouet regards Lyngbya confervoides C. Agardh ex Gomont, L. Lutea (C. Agardh) Gomont ex Gomont, L. semiplena (C. Agardh) J. Agardh and Oscillatoria nigro-viridis Thwaites in Harvey ex Gomont as ecophenes of Microcoleus 1yngbyaceus, Oscillatoria laetevirens Crouan ex Gomont as an ecophene of Microcoleus chthonoplastes, and Oscillatoria salinarum Collins and $\underline{0}$. subuliformis Thwaites in Kützing ex Gomont as ecophenes of Porphyrosiphon notarisii.

Measurement of Physical and Chemical Factors

SALINITY - Salinities were determined with an Industrial Instruments Induction Salinometer, Model RS-7A, from water samples taken periodically in the collection area.

WATER TEMPERATURE - A Foxboro thermograph installed at the end of the VIMS laboratory pier (about 100 yards from the collection area) gave a continuous reading of bottom water temperature in degrees Fahrenheit. Daily extremes and hourly values were converted to degrees Celsius for calculation of dally averages and ranges. 
AIR TEMPERATURE - A Belfort Hygro-Thermograph (No. 5-594), employing a bimetallic assembly housed in a standard ventilated instrument shelter, provided a continuous reading of air temperature in degrees Fahrenheit. From this record, daily extremes and averages (based on hourly values) were tabulated in degrees Celsius. The instrument was located atop the main laboratory building of the institute, Maury Hall.

TIDES - From the Coast and Geodetic Survey tidal station, located at the end of the VIMS laboratory pier, tidal heights at hourly intervals and times and helghts of high and low waters were obtained. Mean low water (MLW), mean tide level (ML) and mean high water (MHW) were determined for each collection by tabulating the respective tidal heights from a 30 day period prior to sampling. This 30 day period was selected because a population of algae could become extablished or be decimated in this time interval.

\section{Statistical Analysis}

By summarizing the data for all collections, a fairly accurate estimate of the intertidal range for each species was determined. Relative positions of floral assemblages and the degree of relationship (expressed as percent) between each and every $4 \mathrm{~cm}$ height in the intertidal zone was determined using Jaccard's coefficient of community (Jaccard, 1902). A trellis diagram $\mathcal{N}^{\text {for }}$ illustration. The formula for Jaccard's coefficient is:

$$
C J=\frac{c}{(a+b-c)} \times 100
$$

where $c$ is the total number of specles common to both heights and a and $b$ are the number of species in each height respectively. 


\section{RESULTS}

Ten collections were made between January and June, 1967, six from aged wooden pilings (February 16, March 14 and 29, April 24, May 30 and June 20), two from the temporary substrata for determining colonization (June 1 and 30 ) and two from the temporary substrata for determining succession (June 1 and 30 ).

Twenty-six species of marine algae were collected and identified during the collection period from February to June. of these, seven wer Cyanophyta, eight Rhodophyta, ten Chlorophyta and one Phaeophyta. Species that were previously not reported from Virginia are listed in Table $I$, and a complete list of all species collected is given in Appendix A.

Monthly average salinities for the period January, 1966 to June, 1967 show a yearly cyclic variation with maximum values (23$24 \%$ ) occurring in January and February, 1966 and then again in September, 1966 and January, 1967. Minimum values (18-19\%\%) occurred in May, 1966 and April, 1967 (Fig. 3). Salinity variations during a single tidal fluctuation are generally zbout $0.5 \%$

Water temperatures were lowest during the end of February and the beginning of March; subsequently a steady increase occurred through June (Fig. 4). Air temperature was quite variable throughout the spring with a recorded low of $-9.4 \mathrm{C}$ on February 25 and a high of $37.8 \mathrm{C}$ on June 25. The average daily air temperature is given in Figure 5. A monthly summary of the mean lows, mean highs and means for water 
TABLE I

SPECIES PREVIOUSLY UNREPORTED FROM VIRGINIA

Phaeophyta

Ectocarpus confervoides (Roth) Le Jolis

\section{Chlorophyta}

Enteromorpha compressa (Linnaeus) Greville Enteromorpha erecta (Lyngbye) J. Agardh Enteromorpha prolifera (Mülller) J. Agardh Monostroma leptodermum Kjellman Ulothrix flacca (Dillwyn) Thuret

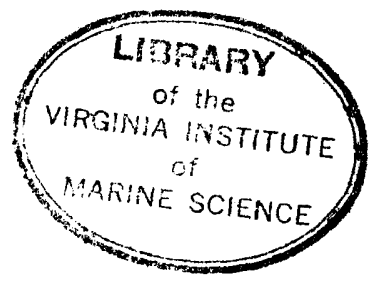




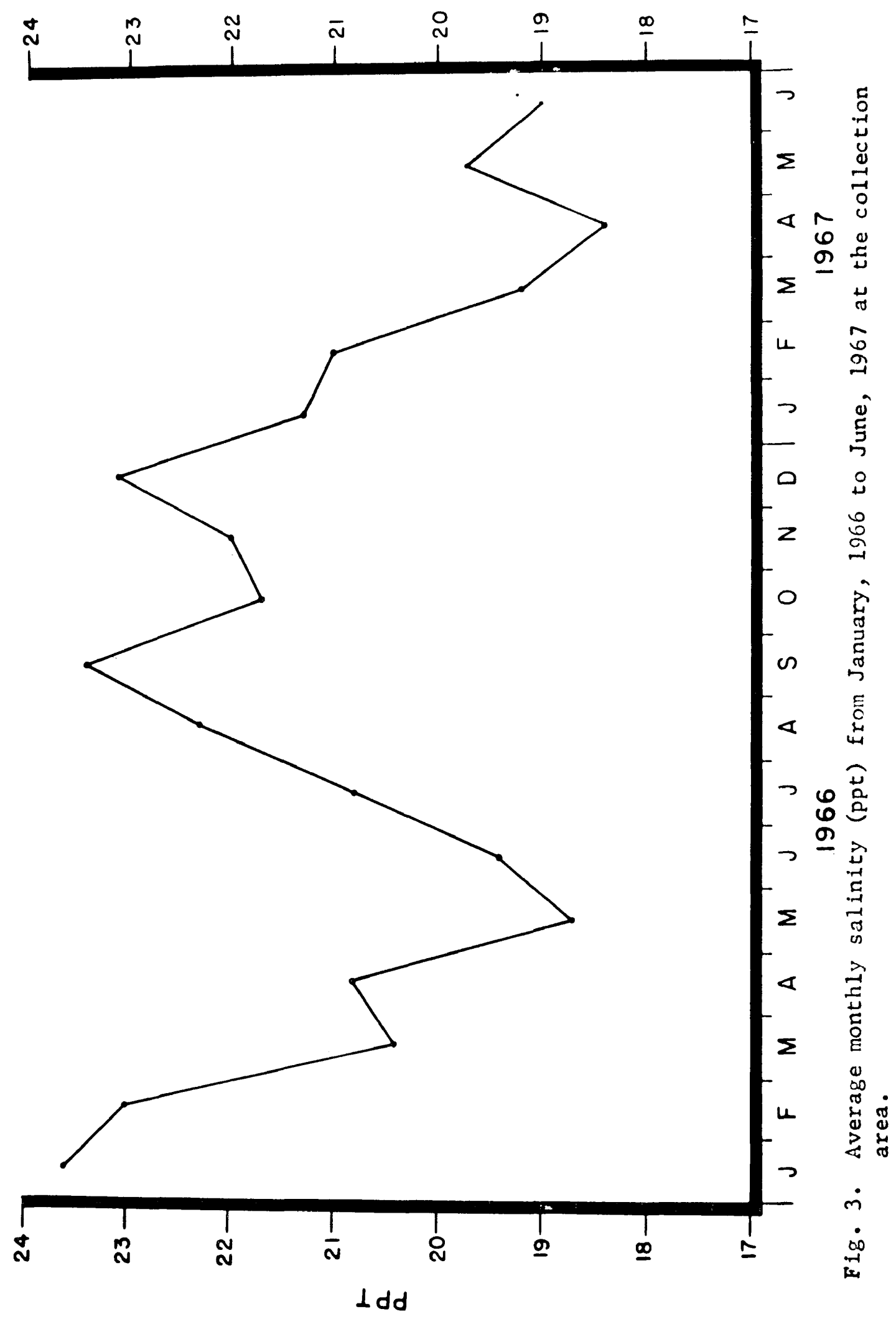




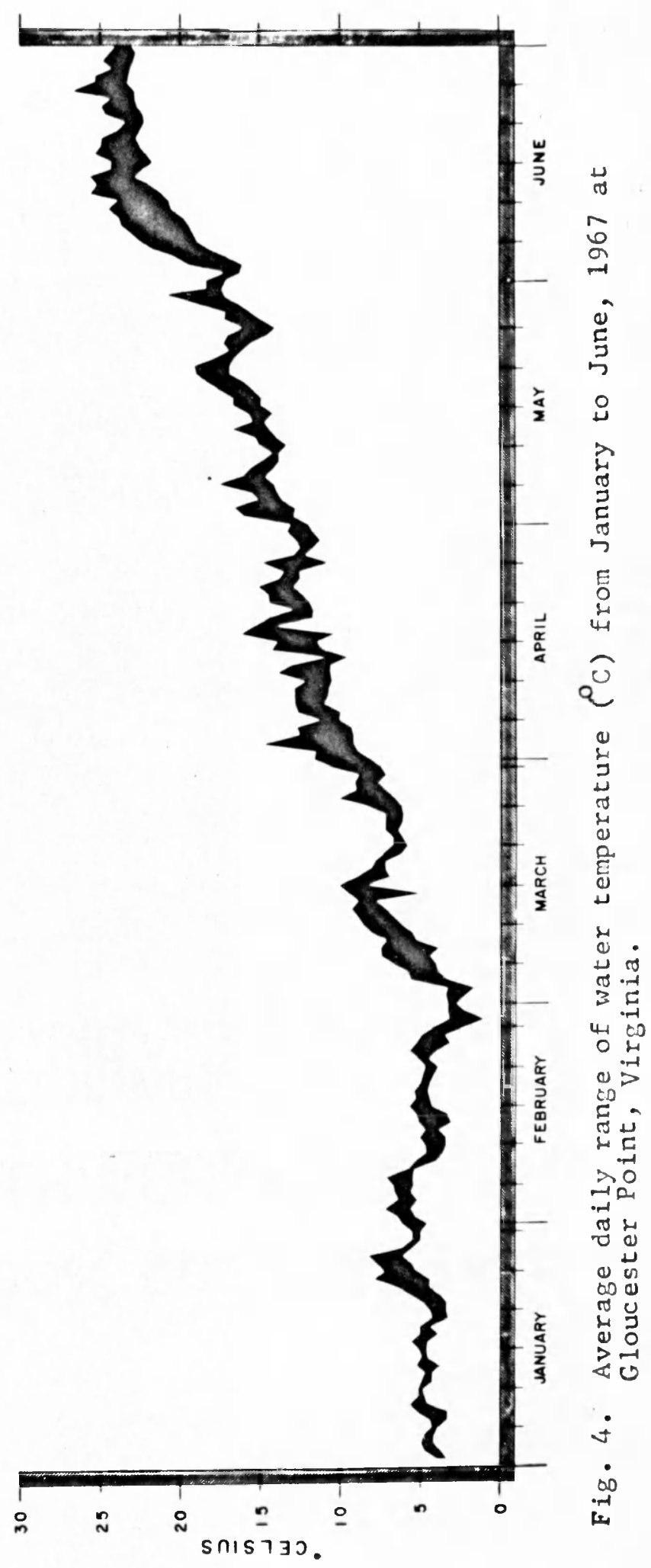




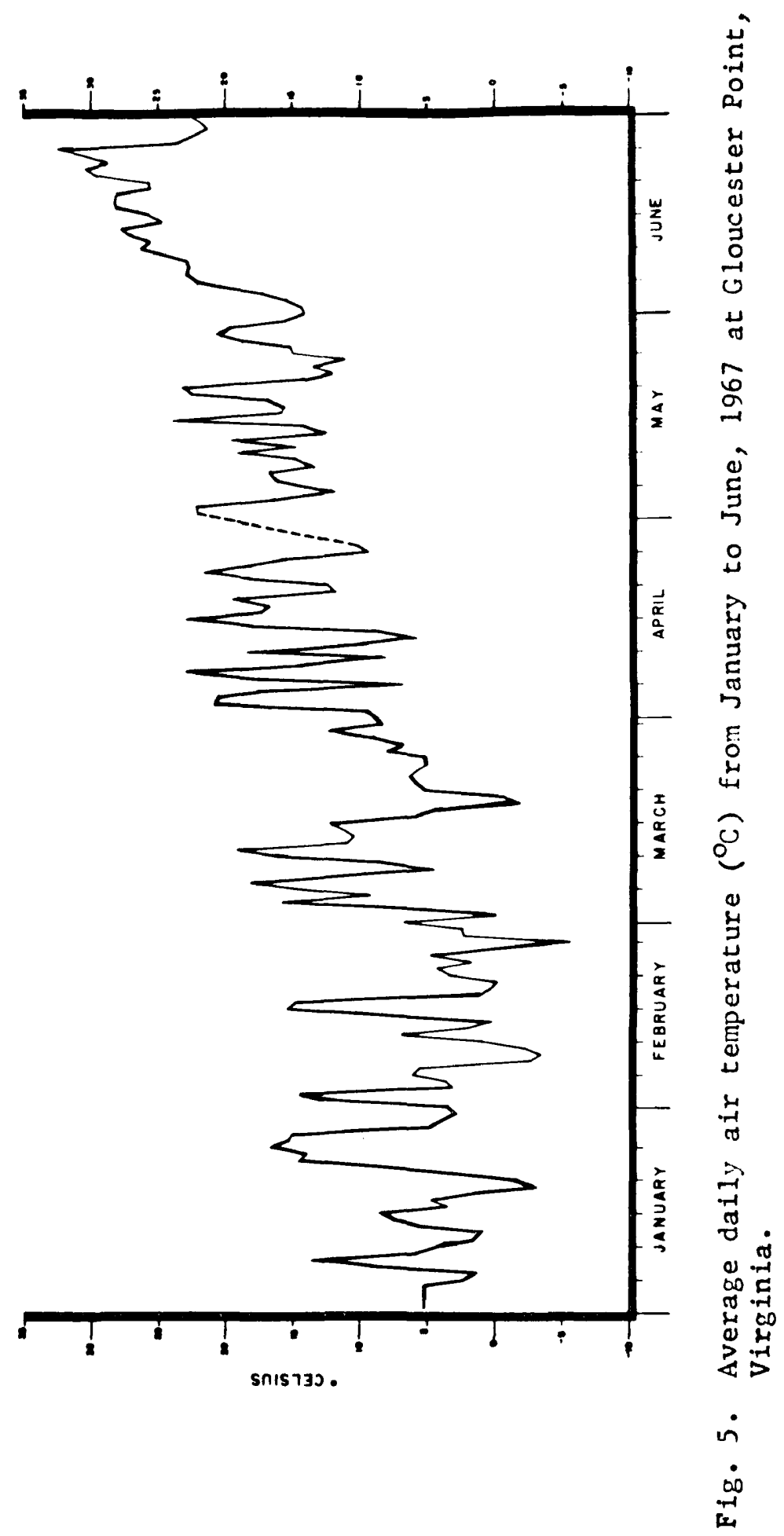


temperature and air temperature are given in Appendix B.

\section{Seasonality}

Table II shows the record of occurrence of algae collected from all substrata employed in the study. Ulva lactuca, Porphyra unbilicalis and Callithamion byssoldes were particularly abundant in the February collection. A few specimens of Polysiphonia denudata, P. nigrescens, Dasya pedicellata, Bryopsis plumosa, Enteromorpha compressa, E. er.ecta, $\underline{E} \cdot \underline{\text { intestinalis }}$ and $\underline{E} \cdot \underline{\text { linza }}$ were also present. Dasya pedfcellata was collected from the permanent substratum only in February, iowever, this alga was found on other intertidal pilings and oyster shells in the adjacent Zostera beds during June, July and August. Polysiphonia nigrescens, present only in February and March collections, had tetrasporic and cystocarpic representatives in the respective months.

Beginning in March and continuing into June three species characteristic of the spring flora were evident on the collection substrata. These included Ulothrix flacca, which was very abundant on barnacles, Ectocarpus confervoides and Porphyra umbilicalis.

By June many species rather common in the summer flora for the area appeared in the collections, such as Enteromorpha compressa, E. linza, E. intestinalis, E. prolifera, Ceramium rubrum, Polysiphonia denudata and Bangia fuscopurpurea. Small specimens of Ceramium rubrum

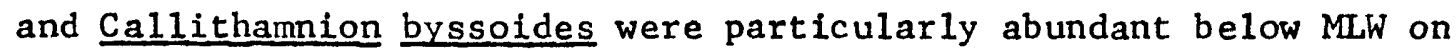
the temporary substrata in June.

With regard to the Cyanophyta, Microcoleus lyngbyaceus and Calothrix crustacea were present throughout the sampling period; the latter was particularly dense in May and June. Entophysalis deusta 
TABLE II

RECORD OF OCUURENCE OF ALGAE COLLECTED FROM ALL SUBSTRATA

\begin{tabular}{|c|c|c|c|c|c|}
\hline SPEC IES & FEB & MAR & APR & MAY & JUN \\
\hline Calothrix crustacea & $\mathbf{x}$ & $\mathbf{x}$ & $\mathbf{x}$ & $\mathbf{x}$ & $\mathbf{x}$ \\
\hline Entophysalis deusta & & $\mathbf{x}$ & $\mathbf{x}$ & $\mathbf{x}$ & $\mathbf{x}$ \\
\hline Microcoleus chthonoplastes & & $\mathbf{x}$ & $\mathbf{x}$ & & \\
\hline M. lyngbyaceus & $\mathbf{x}$ & $\mathbf{x}$ & $\mathbf{x}$ & $\mathbf{x}$ & $\mathbf{x}$ \\
\hline Porphyrosiphon notarisii & & & $\mathbf{x}$ & $\mathbf{x}$ & $\mathbf{x}$ \\
\hline Schizothrix calcicola & & $\mathbf{x}$ & $\mathbf{x}$ & $\mathbf{x}$ & $\mathbf{x}$ \\
\hline Spirulina subsalsa & $\mathbf{x}$ & $\mathbf{x}$ & $\mathbf{x}$ & & $\mathbf{x}$ \\
\hline Bangia fuscopurpurea & & & & & $\mathbf{x}$ \\
\hline Callithamnion byssoides & $\mathbf{x}$ & & & & $\mathbf{x}$ \\
\hline Ceramium rubrum & & & & & $\mathbf{x}$ \\
\hline C. strictum & & & $\mathbf{x}$ & & \\
\hline Dasya pedicellata & $\mathbf{x}$ & & & & \\
\hline Polysiphonia denudata & $\mathbf{x}$ & & & & $\mathbf{x}$ \\
\hline P. nigrescens & $\mathbf{x}$ & $\mathbf{x}$ & & & \\
\hline Porphyra umbilicalis & $\mathbf{x}$ & $\mathbf{x}$ & $\mathbf{x}$ & & \\
\hline Ectocarpus confervoides & & $\mathbf{x}$ & $\mathbf{x}$ & & $\mathbf{x}$ \\
\hline Bryopsis plumosa & $\mathbf{x}$ & & & & \\
\hline Enteromorpha compressa & $\mathbf{x}$ & & & & $\mathbf{x}$ \\
\hline E. erecta & $\mathbf{x}$ & & & & \\
\hline E. intestinalis & $\mathbf{x}$ & & & & $\mathbf{x}$ \\
\hline $\bar{E} \cdot \overline{\text { Iinza }}$ & $\mathbf{x}$ & $x$ & & & $\mathbf{x}$ \\
\hline E. $\overline{\text { minima }}$ & & $\mathbf{x}$ & & & \\
\hline $\bar{E} \cdot \overline{\text { prolifera }}$ & & $\mathbf{x}$ & $\mathbf{x}$ & & $\mathbf{x}$ \\
\hline Monostroma 1eptodermum & & & $\mathbf{x}$ & & \\
\hline Ulothrix flacca & & $\mathbf{x}$ & $\mathbf{x}$ & $\mathbf{x}$ & $\mathbf{x}$ \\
\hline Ulva lactuca & $\mathbf{x}$ & $\mathbf{x}$ & & & $\mathbf{x}$ \\
\hline
\end{tabular}


and Schizothrix calcicola were common during the study period, but neither were found in the first collection. Spirulina subsalsa was present every month but May, however, this was probably the result of a collection anomoly. Microcoleus chthonoplastes was present in March and April and Porphyrosiphon notarisii from April to June.

\section{Colonization and Succession}

The acrylic plastic temporary substrata were inspected monthly, althrough colonization and growth of algae were not evident until the June 1 collection despite the fact that the substrata were set out in January. Thus, algae had commenced setting on these substrata during May. Detrital matter and sediment were not present on either set of temporary substrata until late April, althrough they were found on the colonization substrata in the May and June collections.

In the first collection (June 1) from succession plates (i.e., those plates left in the holder throughout the spring) five algal species were present. Also some small filaments of Enteromorpha, which could not be identified to species, occurred only at $-34 \mathrm{~cm}$ (Fig. 6). E. intestinalis was the only species found above MLW, ranging from -30 to $+10 \mathrm{~cm}$. Ceramium rubrum, Qallithamnion byssoides, Ectocarpus confervoides and Enteromorpha compressa were limited to below MLW. Some of the specimens included in the collections from these plates were taken from sessile animals attached to the succession substrata.

From the temporary substrata used to determine colonization (i.e., those plates cleaned monthly of all detritus and algal growth), the first collection, June 1, showed four species present 


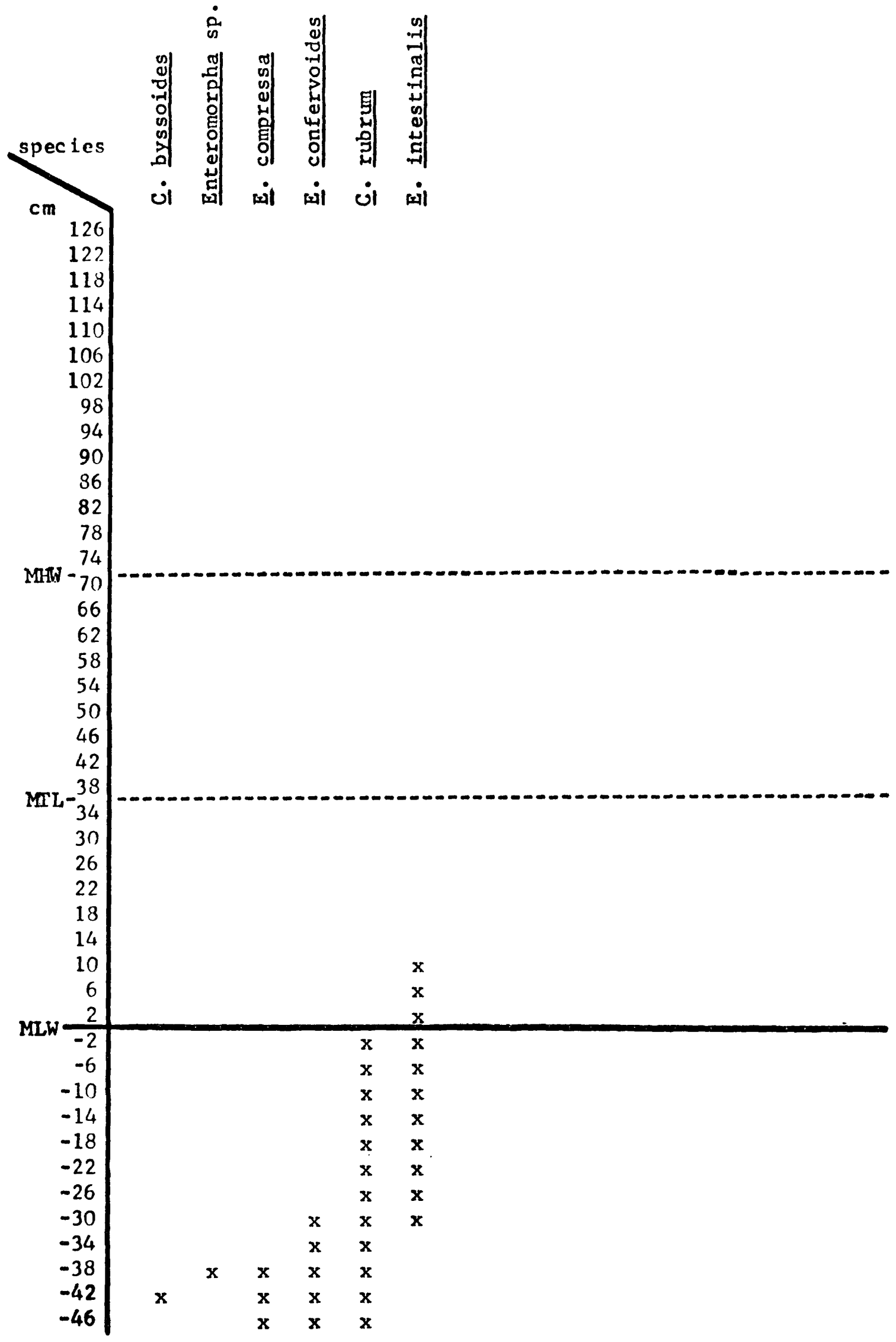

Fig. 6. Intertidal zonation on succession substrata, June 1 . 
(Fig. 7), two of which (Ceramium rubrum and Ectocarpus confervoides) were also present on the succession substrata on the same collection date. Enteromorpha prolifera ranged from -46 to $-42 \mathrm{~cm}$. Ceramium rubrum was found only at $-42 \mathrm{~cm}$. Ectocarpus confervoides and some unidentified filaments of Enteromorpha were found as high as $-14 \mathrm{~cm}$ and ranged downward to -46 and $-38 \mathrm{~cm}$ respectively. Ulothrix flacca occurred between +10 and $+22 \mathrm{~cm}$.

A second collection from both temporary substrata was made on June 30 (Figs. 8, 9) and the four species present on the colonization substrata were also found on the succession substrata. Only two of the species present on the first collection date were in evidence on June 30: Callithamnion byssoides found only on the succession substrata at $-42 \mathrm{~cm}$ June 1 occurred from -34 to $-22 \mathrm{~cm}$ and -30 to $-18 \mathrm{~cm}$ on the succession and colonization substrata respectively. Enteromorpha intestinalis, present on the succession substrata June 1 from -30 to $-10 \mathrm{~cm}$, had ranges of -22 to $+42 \mathrm{~cm}$ on the succession substrata and -46 to $+30 \mathrm{~cm}$ on the colonization substrata in the second collection.

On June 30 Enteromorpha 1inza ranged from -2 to $+6 \mathrm{~cm}$ and Polysiphonia denudata occurred from -26 to $-2 \mathrm{~cm}$ on the colonization substrata; on the succession substrata the ranges were -6 to $+18 \mathrm{~cm}$ and -34 to $-6 \mathrm{~cm}$ respectively. Other species present only on the succession substrata included Spirulina subsalsa, Ulva lactuca and Microcoleus 1yngbyaceus. 


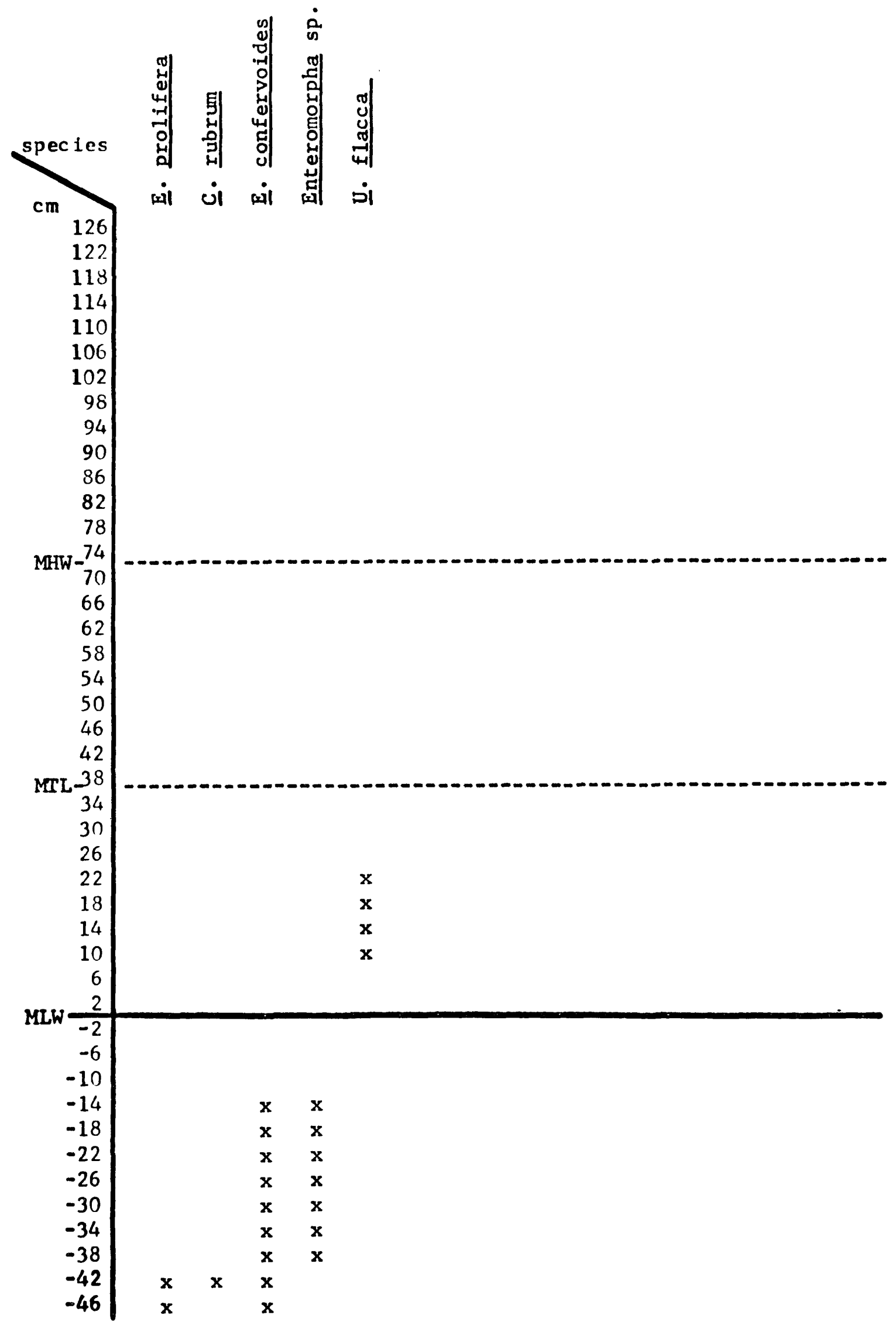

Fig. 7. Intertidal zonation on colonization substrata, June 1. 


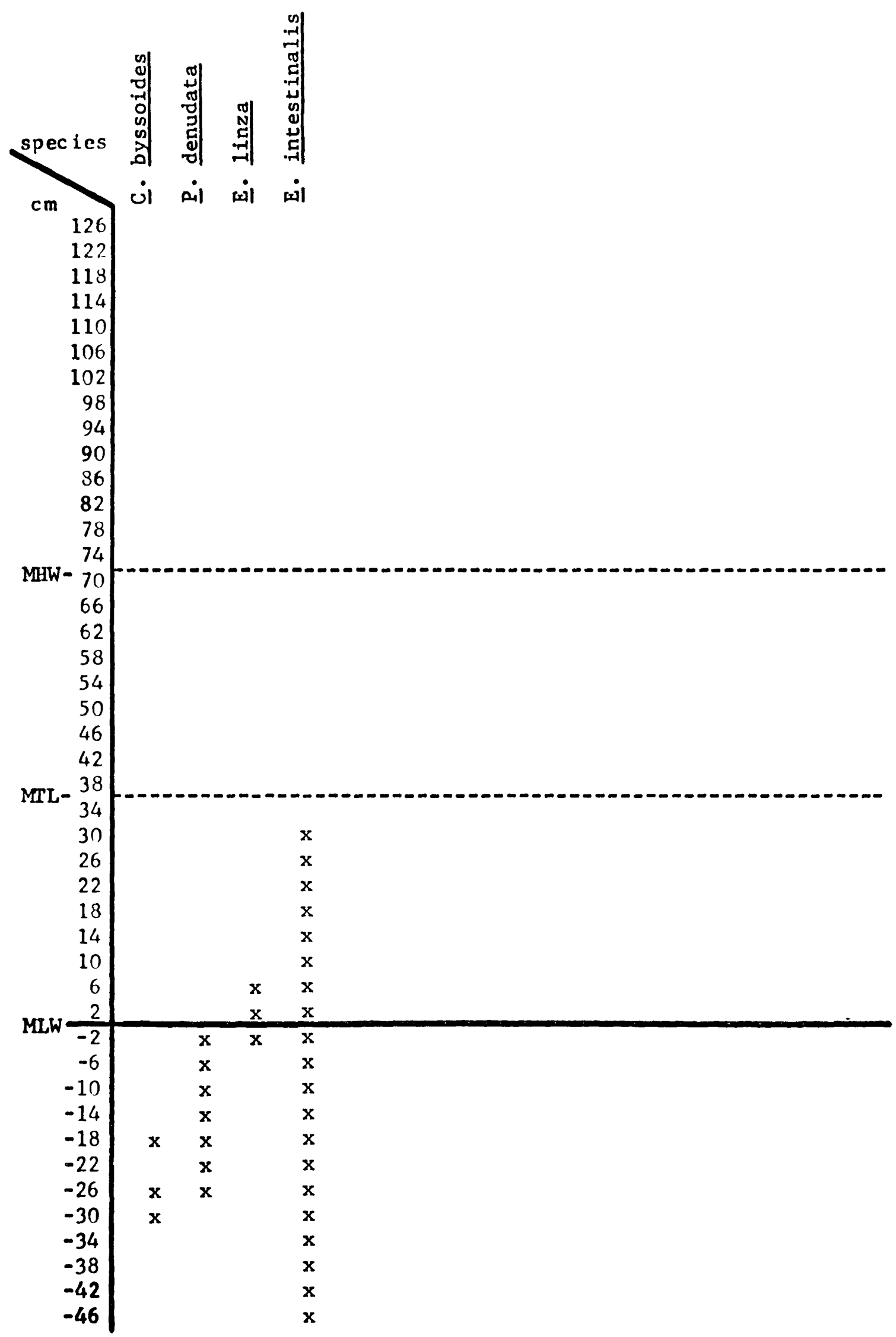

Fig. 8. Intertidal zonation on colonization substrata, June 30. 


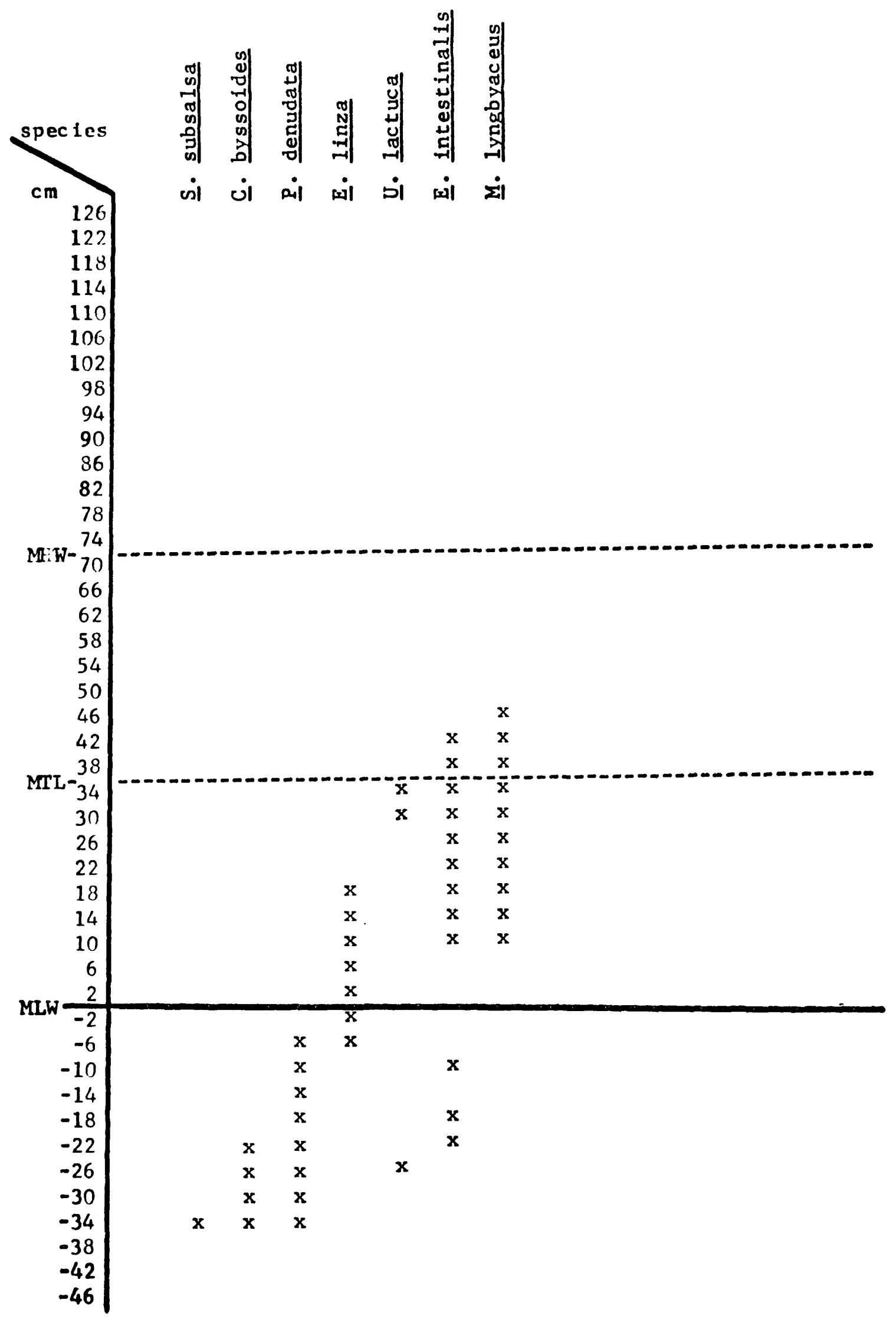

Fig. 9. Intertidal zonation on succession substrata, June 30. 


\section{Intertidal Zonation}

Figures 10 to 15 depict the intertidal floral distribution on aged wooden pilings (permanent substrata): Fig. 10, February 16; Fig. 11, March 14; Fig. 12, March 29; Fig. 13, April 25; Fig. 14, May 30; and Fig. 15, June 20 .

A summary of the intertidal floral ranges is shown in Figure 16 for which the results of each collection have been collated. All species of Rhodophyta, except Bangla fuscopurpurea and Porphyra umbilicalis, were confined to below MLW; species of Chlorophyta, Cyanophyta and one Phaeophyte had ranges extending above MLW.

The trellis diagram in Figure 17 shows the degree of floral relationship between $4 \mathrm{~cm}$ intervals in the intertidal zone. Between -34 and $-10 \mathrm{~cm}$ there was better than a 75 percent association, which results from few upper or lower species distribution limits in this zone; however, from $-14 \mathrm{~cm}$ to $\mathrm{MW}$ the degree of association between adjacent intervals varied from 46 to 78 percent because many of the intertidal constituents have their lower distribution limits in this area.

From MLW to $+62 \mathrm{~cm}$ there was better than a 75 percent association between at least two and sometimes as many as six adjecent $4 \mathrm{~cm}$ intervals. The breadth of this 75 percent plus association over $4 \mathrm{~cm}$ intervals varied because 11 species had their upper distribution 1 imits within this span. From +62 to $+70 \mathrm{~cm}$ the association was between 50 and 75 percent; this area formed the upper 1imit for Enteromorpha linza, Porphyra umbilicalis and Microcoleus lyngbyaceus. Also, the presence of Bangia fuscopurpurea at only one intertidal interval $(+66 \mathrm{~cm})$ adds to this phenomenon. The less than 50 percent relationship between +74 


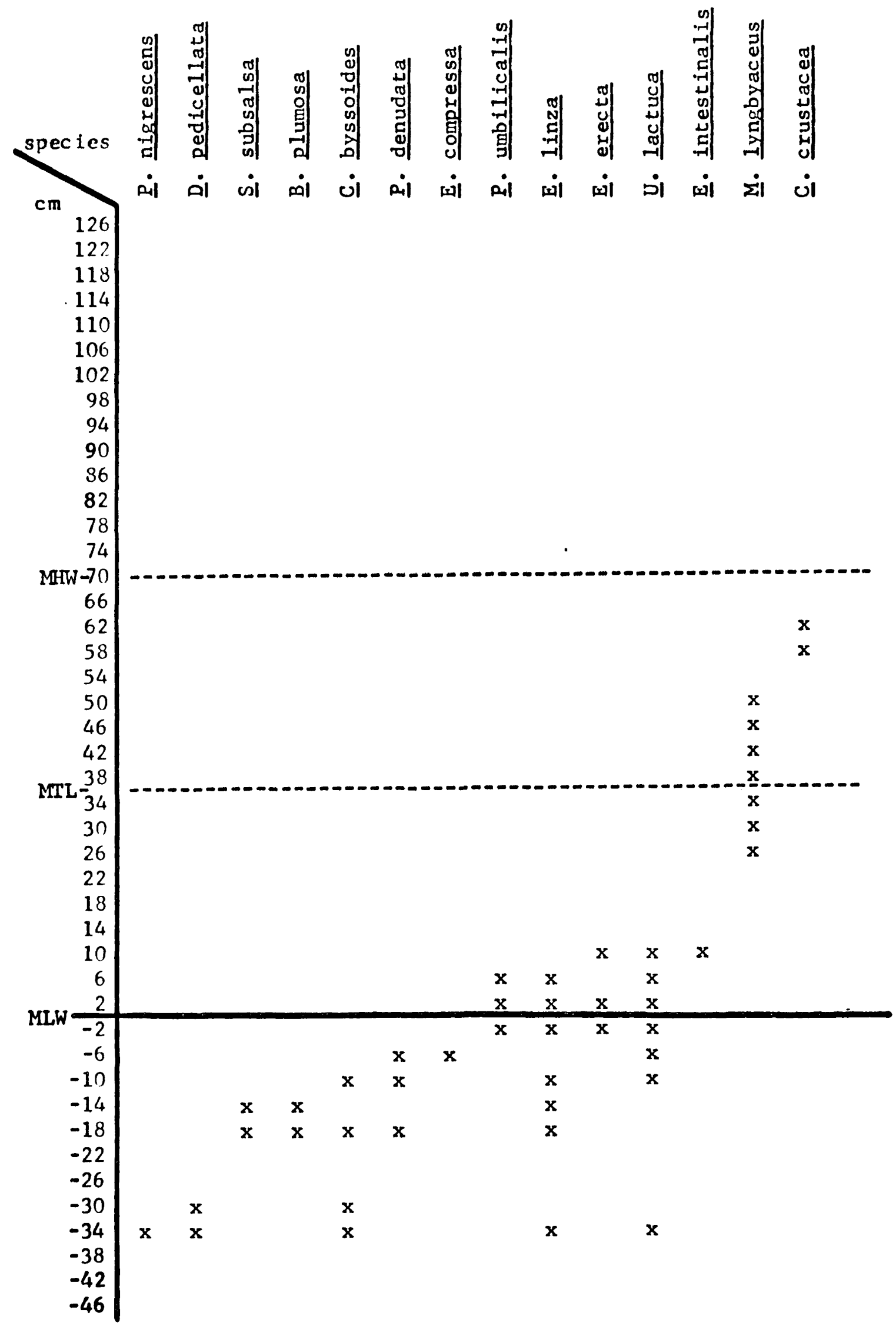

Fig. 10. Intertidal zonation on the permanent substratum, February 16. 


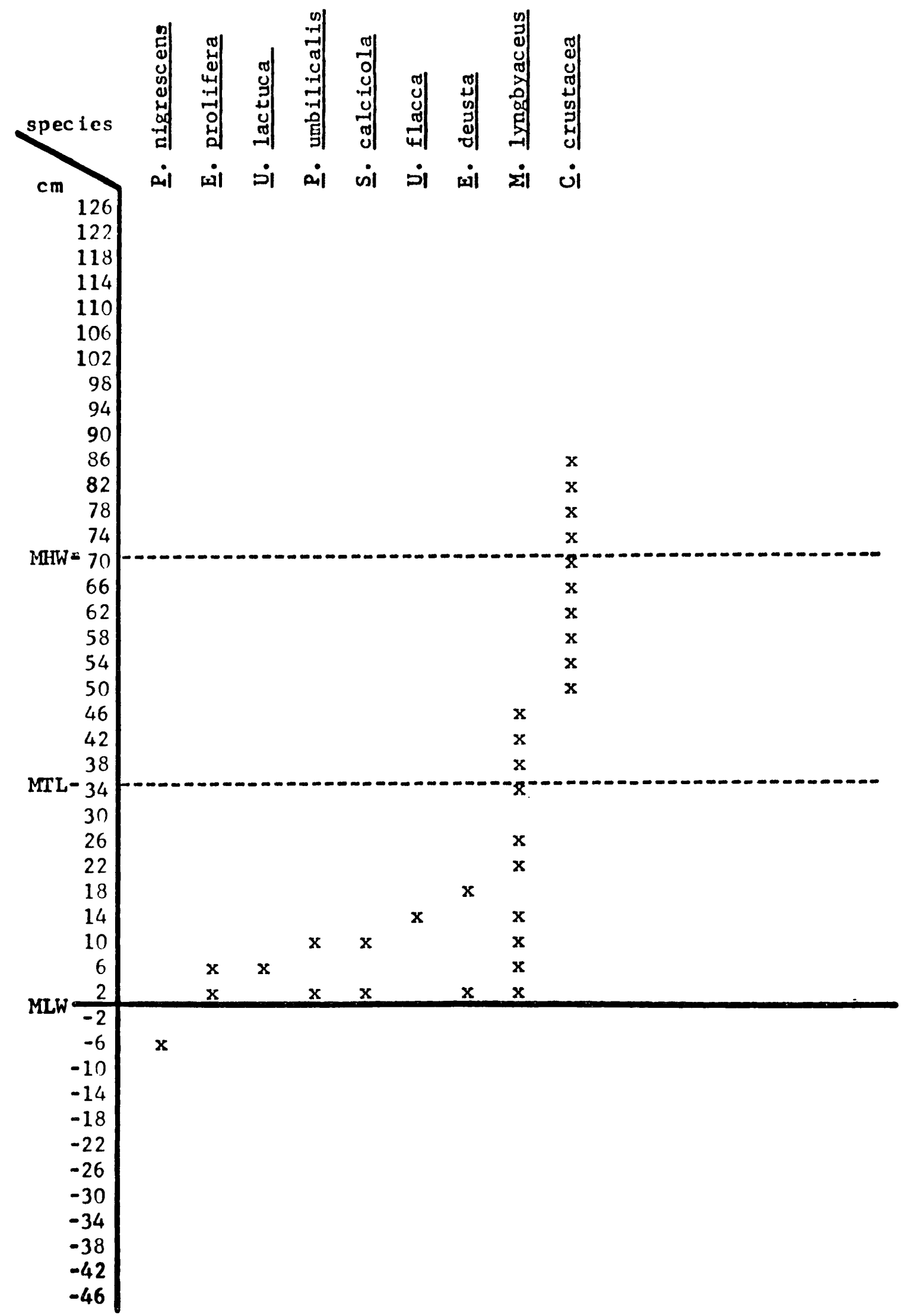

Fig. 12. Intertidal zonation on the permanent substratum, March 14. 


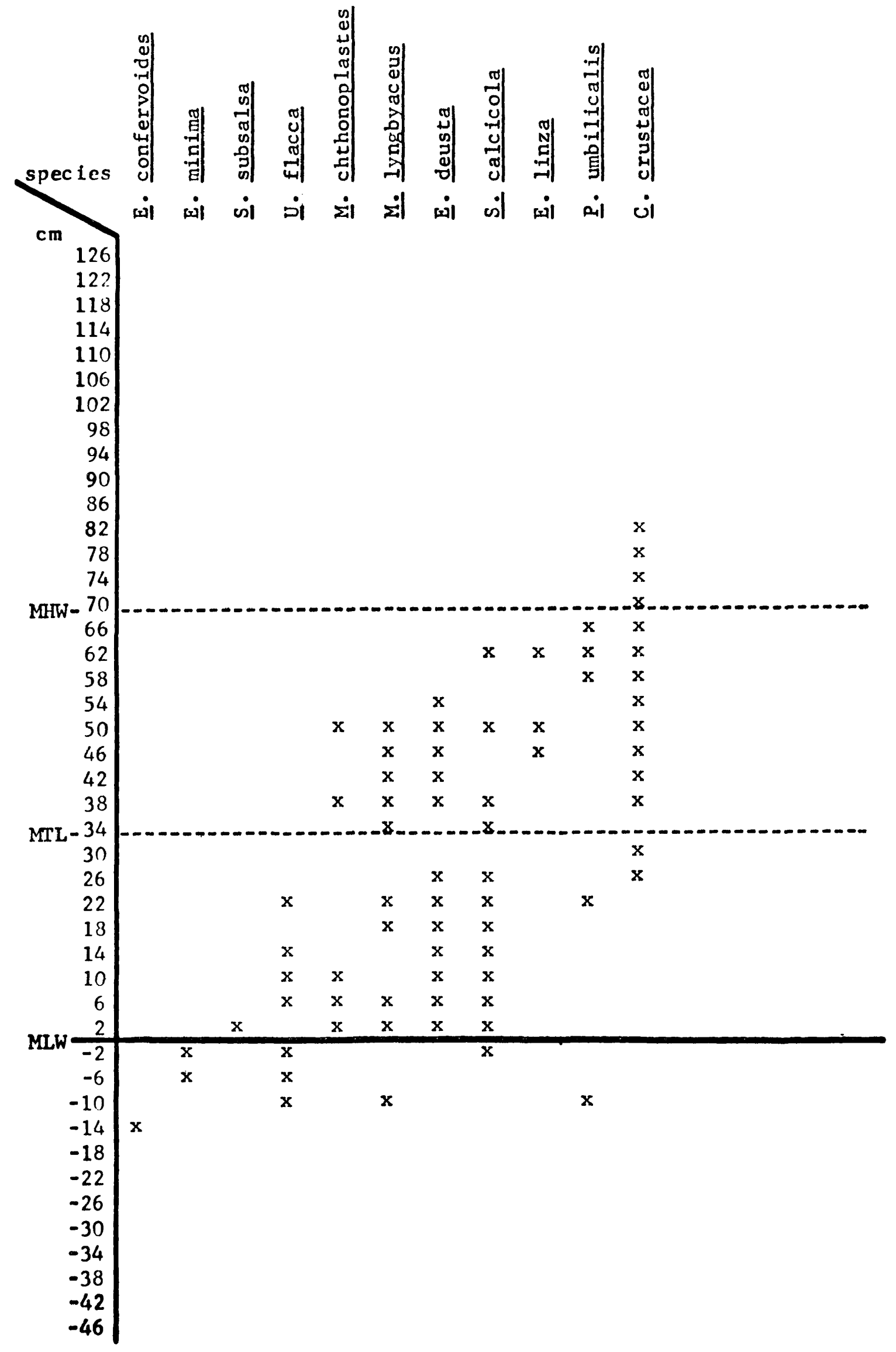

Fig. 12. Intertida1 zonation on the permanet substratum, March 29. 


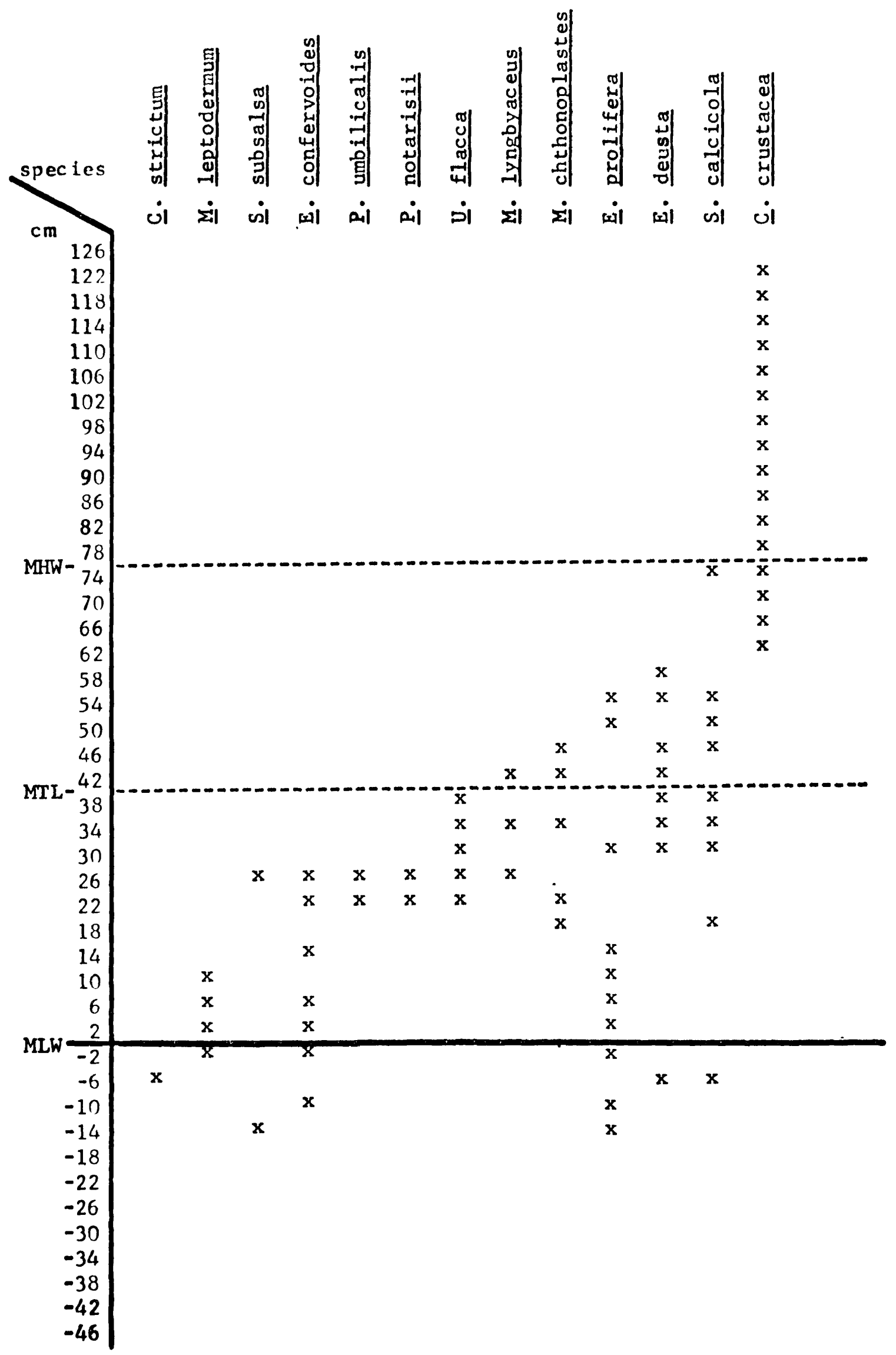

Fig. 13. Intertidal zonation on the permanent substratu, April 25. 


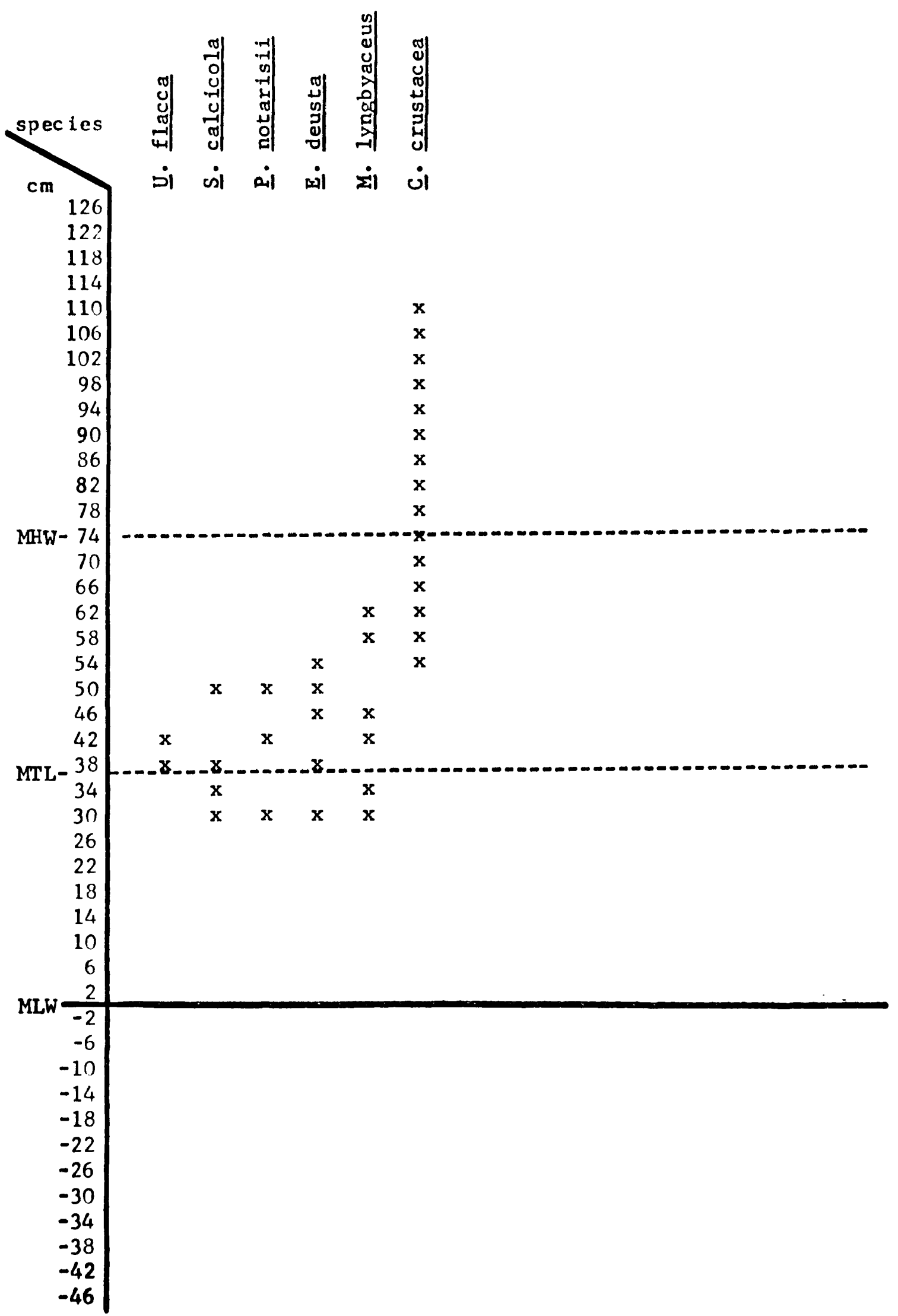

Fig. 14. Intertidal zonation on the permanent substratum, May 30. 


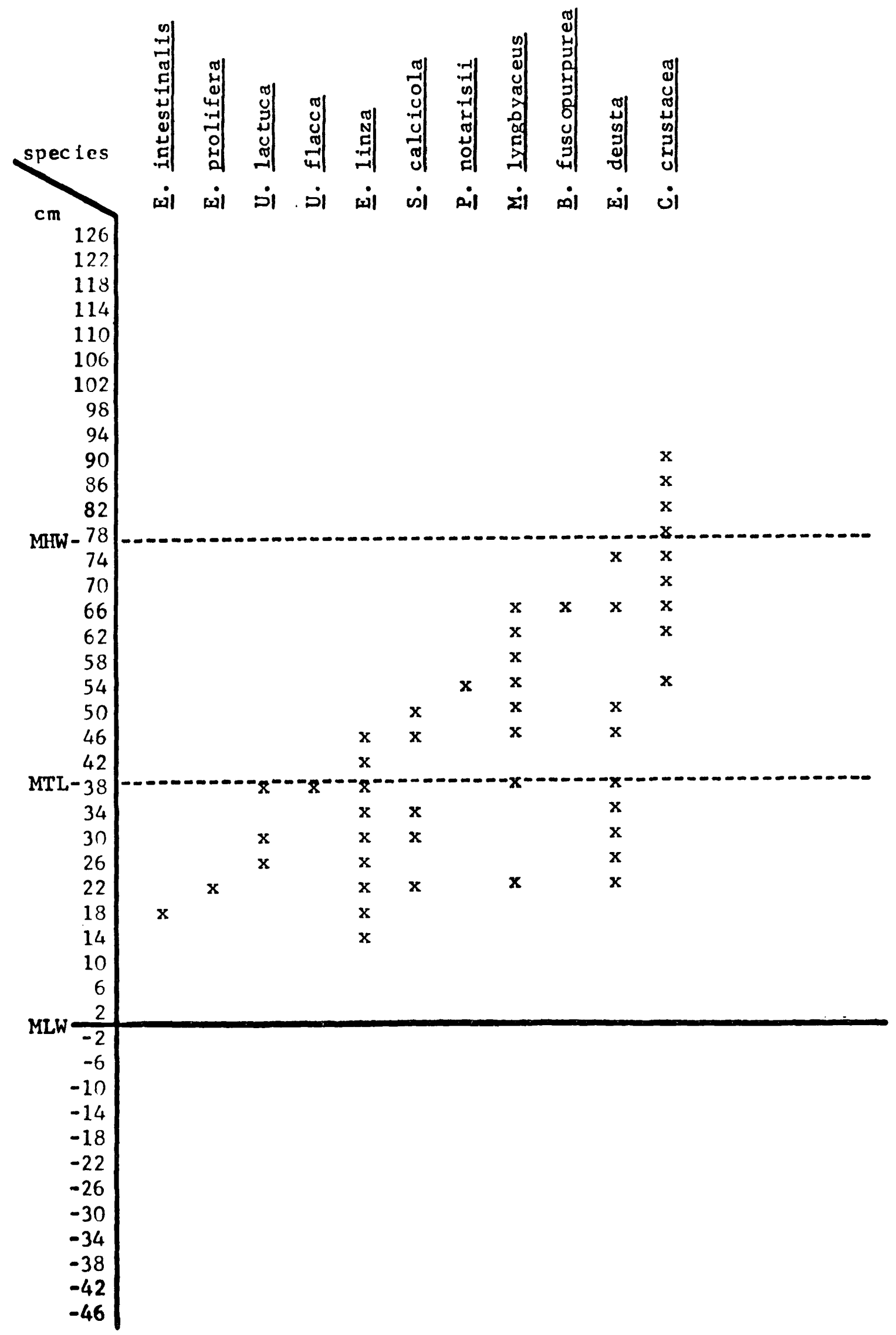

Fig. 15. Intertidal zonation on the permanent substratum, June 20. 


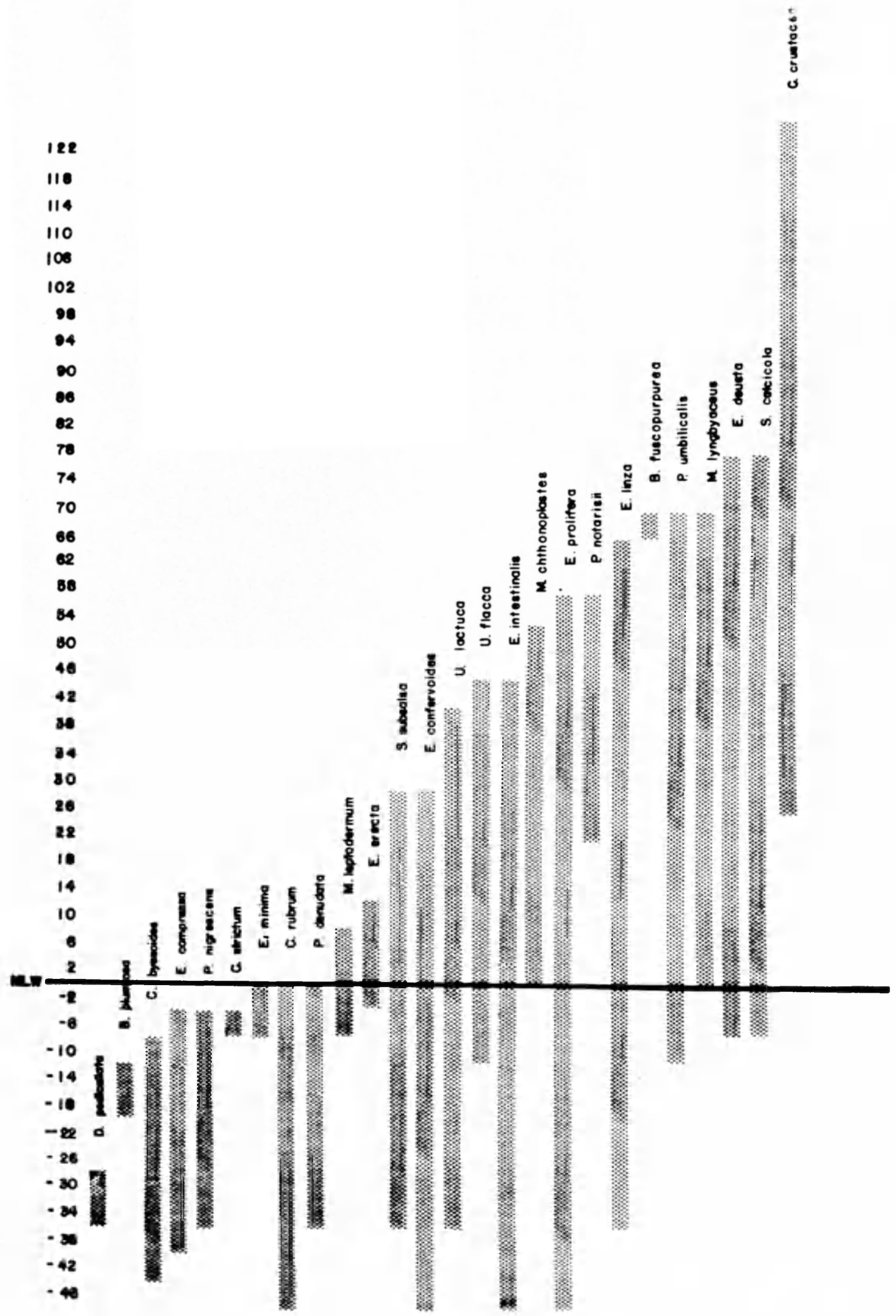

Fig. 16. A summary of the zonation of intertidal flora. 


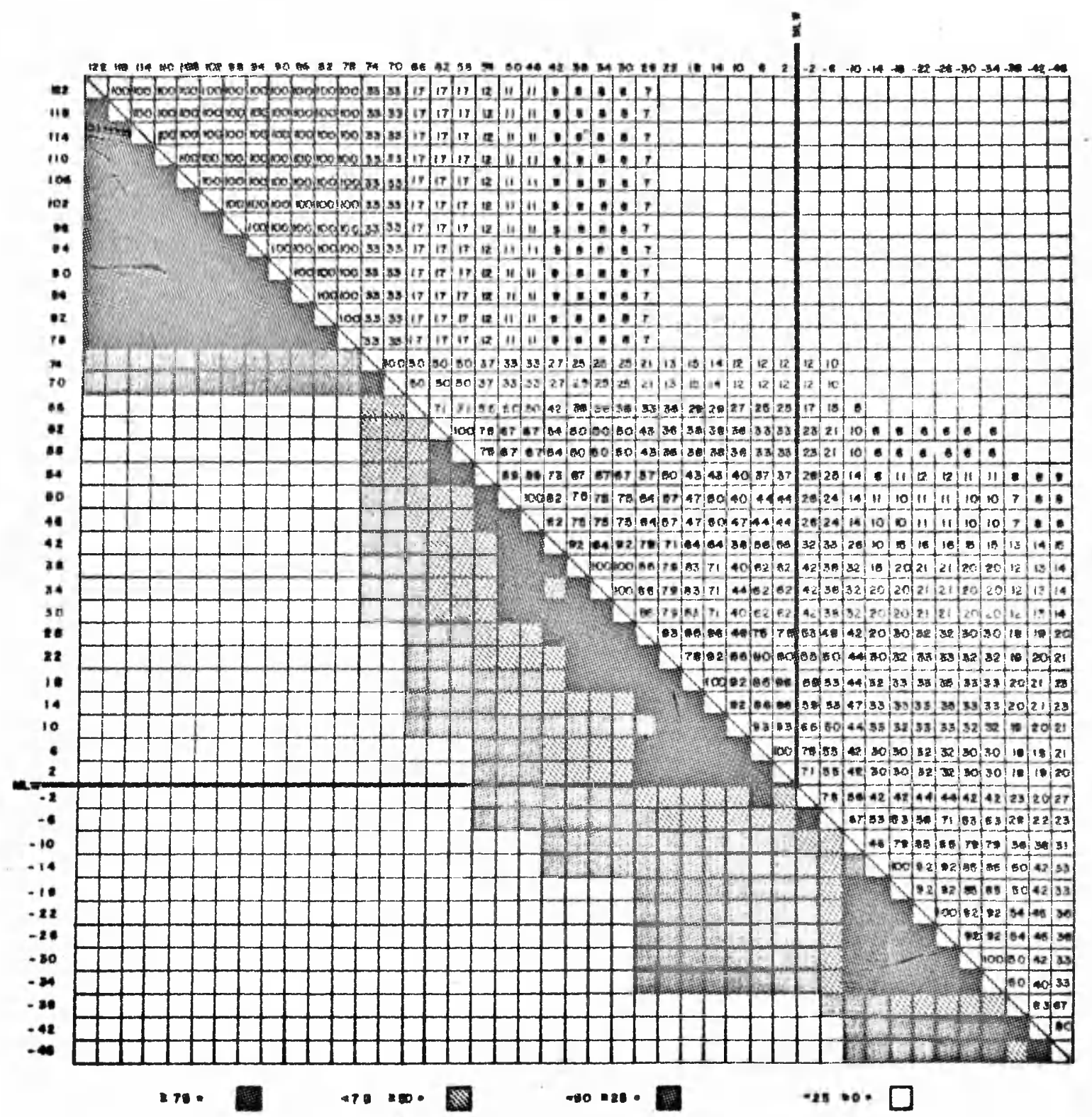

Fig. 17. Jaccard's coefficients of simflarity for all cm intervals of the intertidal zone. 
and $+73 \mathrm{~cm}$ was due to the formation of the upper limit of Entophysalis deusta and Schizothrix calcicola. From +78 to $+122 \mathrm{~cm}$ the 100 percent relationship resulted from the presence of only a single species, Calothrix crustacea. 


\section{DISCUSS ION}

The presence or absence of a marine algal species in a particular environment is dependent upon the physical and biological conditions of the mileu and available substrata. In Chesapeake Bay and its estuaries substrate types are limited to calcareous matter (primarily shells of Crassostrea virgintca, Balanus spp. and Mercenaria mercenaria), wooden artifacts (mainly creosoted pilings), fleshy sessile organisms such as sponges and the tunicate Molgula

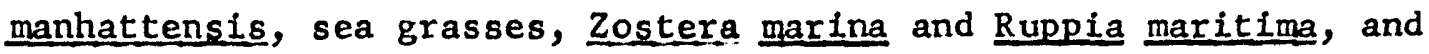
various salt marsh anglosperms. Except for a few breakwaters, rocky substrata are scarce. Wave-action within the Bay rarely attains the magnitude that prevails in habitats exposed to the open sea. Swift tidal currents are present, especially in the tributaries, increasing turgidity, which reduces light penetration into the water and promotes burial of many germlings. Salinities vary from about $27 \%$ at the mouth of Chesapeake Bay to freshwater in the tributaries; annual water temperature range is from about 0 to $28 \mathrm{C}$. All of the aforementioned factors result in a reduced number of marine algal species in Chesapeake Bay compared with more northern and southern regions of the Atlantic coast of North America and explain why only 26 species were found in this study.

Whether a species appeared and/or disappeared curing this study period may be due to the observed decrease in salinity or the increase in water temperature or a combination of both. All species 
in this study are normally found in areas with salinities greater than $24 \%$. In April, when minimum salinity values were recorded (18-19\% $\%$, many of the winter species had disappeared and the summer flora had not yet appeared. The seasonal temperature variation probably influences the seasonal presence of many species, but the temperature-species relationship was not analyzed because of the intervening salinity variable.

All species of Cyanophyta are believed to be present year around. The peculiar intertidal distributions noted in the individual collections and interrupted seasonal occurrence in some instances most likely resulted from the formation of ecophenes. Calothrix crustacea, Spirulina subsalsa and Microcoleus lyngbyaceus are common forms; the latter species is primarily in the ecophene forms of Lyngbya confervoides and Oscillatoria nigro-viridis (Francis Drouet, personal comanication). Spirulina subsalsa forms skeins on the lower portions of pilings and mats in the adjacent zostera beds during the spring and summer, especially during extended periods of reduced vave-action.

Two other factors which may have influenced the nunber and distribution of species found in this study are: (1) a period of extremely cool air temperatures in late February $(-9.4 \mathrm{C}$ minimum) which promoted ice formation on the pilings for several days; and (2) a large anount of crude oil, found drifting in the area on March 23, which literally covered some pilings to a thickness of two or more inches in some cases and reached a height of $94 \mathrm{~cm}$ above MLW. To what extent either of these factors altered the floral cornosition is uncertain; collections in March (Figs. 11, 12) and April (Fig. 13) after the events did not show gross reductions in the number or distribution of species. 
Changes occurring on the succession substrata between June 1 and June 30 collections were: (1) continued development of two species (Callithannion byssoides and Enteromorpha intestinalis); (2) colonization by five species (Spirulina subsalsa, Polysiphonia denudata, Enteromorpha linza, Ulva lactuca and Lyngbya confervoides); and (3) the disappearance of three species (Enteromorpha compressa, Ectocarpus confervoides and Ceramium rubrum).

The species found on the colonization substrata June 1 Enteromorpha prolifera, Ulothrix Elacca, Ectocarpus confervoides and Ceramium rubrum) were entirely different from those found on June 30 . Callithamnion byssoides, Polysiphonia denudata, Enteromorpha linza and E. intestinalis) (Figs. 7,9). Ectocarpus confervoides and Ulothrix flacca were nearing the end of their spring seasonal appearance by June 1. Callithamnion byssoides and Polysiphonia denudata, both common in the summer were making their first appearance. It is apparent that a seasonal change in the local floral composition occurred during this period.

The results of this study do not portray an intertidal zonation characteristic of open coastal areas where conspicuous banding of several macroscopic species is generally the rule. With the exception of Calothrix crustacea, Porphyrosiphon notarisii and Bangia fuscopurpurea all of the intertidal species with ranges above MLW had continuous distributions extending down to and below MLW (Fig. 16). Earle and Humm (1964) found similar floral distribution patterns in Beaufort Harbor, N. C. The exact point of the lower extensions of many species could not be determined because collections from the permanent substrata were made only down to the level of low tide for the collection 
date, which usually coincided with extreme low water spring tide for the month.

Bryopsis plumosa, Enteromorpha minima, E. compressa, Dasya pedicellata, Callithamnion byssoides, Polysiphonia nigrescens, $\underline{\text {. }}$ denudata, Ceramium strictum and $\underline{\mathrm{C}}$. rubrum did not have distributions extending above ML. This floral group, with better than a 75 percent association between -34 and $-10 \mathrm{~cm}$, comprised a zone comparable to the infralittoral fringe of $T$. A. Stephenson and A. Stephenson (1949). In other intertidal studies on this coast: Kingsbury (1962) found similar distributions for Polysiphonia nigrescens, Dasya pedicellata and Bryopsis plumosa; Earle and Humm (1964) found Polysiphonia denudata only below MLW; and Taylor (1957) reported Enteromorpha minima from the lower littoral zone.

A diminishing degree of floral association was evident from MLW to $+74 \mathrm{~cm}$ (Fig. 17). Between +62 and $+66 \mathrm{~cm}$ and again at $+74 \mathrm{~cm}$ the degree of association was less than 75 percent where several species reached their uppermost limit. The midlittoral zone, between approximately MLW and $+74 \mathrm{~cm}$, contained 17 species extending to various heights with a reduction in the number of constituents progressively higher in the intertidal zone. Seven floral levels were recognized in the midlittoral zone as follows:

(1) Monostroma:Leptodermum and Enteromorpha erecta, present only during late winter and early spring, formed the lowest intertidal level, extending to a height of +10 to $+14 \mathrm{~cm}$. This floral association was not conspicuous upon casual observation; neither species being we11-developed at any time. 
(2) Splrulina subsalsa and Ectocarpus confervoides constituted the next highest intertidal level, attaining an elevation of $+26 \mathrm{~cm}$. E. confervoides is a late spring to early summer species in this area and individual plants were about $5 \mathrm{~cm}$ long. Spirulina subsalsa was quite conspicuous as it formed very dark gelationous skeins on the pilings, especially in late spring.

(3) Thre conspicuous species of Chlorophyta Ulothrix flacca, Ulva lactuca and Enterororpha intestinalis), extending up to +38 to $+44 \mathrm{~cm}$, comprised the third intertidal level. Ulothrix flacca formed dense tufts during March, April and May around the orifice of barnacles.

(4) Microcoleus chthonoplastes, Enteromorpha prolifera and Porphyrosiphon notarisii formed the next highest intertidal level at about +50 to $+54 \mathrm{~cm}$. It should be noted that $\underline{P}$. notarisii did not extend below MLW, but ranged from +22 to $+54 \mathrm{~cm}$.

(5) The fifth intertidal leve1, at about +62 to $+66 \mathrm{~cm}$, consisted of Enteromorpha 1inza, Poxphyra umbilicalis and Microcoleus lyngbyaceus all of which extended downward to MLW and below. M. Iyngbyaceus and Enteromorpha linza are present year around, but Porphyra umbilicalis is present only during the spring. $\underline{\mathrm{P}}$. umbilicalis appears to be found in the upper reaches of its intertidal distribution only during the latter part of the spring or early sumer.

(6) Eangia Euscopurpureg formed a band at $+66 \mathrm{~cm}$ and constituted the sixth intertidal level. This species did not form a conspicuous color band. Found on this coast from Newfoundland to Florida (Taylor, 1957; 1960), it occupies a similar position in other areas (Johnson and Skutch, 1928; Earle and Humm, 1964; Humm, 1962). 
(7) Entophysalis deusta and Schizothrix calcicola, which penetrate calcareous substrata, comprised the seventh intertidal leve1, having a maximum height of $+74 \mathrm{~cm}$. Earle and Humm (1964) found Entophysalis deusta to occupy a similar position in Beaufort Harbor. The intertidal distribution of these two species is apparentIy determined by the vertical height of barnacles.

Calothrix crustacea was the only species found in the supralittoral fringe (above $+74 \mathrm{~cm}$ ), although it did extend downward into the midlittoral zone. Immediately above the upper limits of Entophysalis deusta and Schizothrix calcicola, filaments of Calothrix crustacea formed conspicuous tufts about $0.5 \mathrm{~cm}$ thick and very deep green in color. Higher in the supralittoral fringe, however, the filaments lay flat against the pilings and were black in color. Thus, for the study period, intertidal pilings in the York River estuary at Gloucester Point may be vertically divided into three floral regions found similarly in other areas by $T$.A. Stephenson and A. Stephenson (1949, 1950, 1952, 1954): an infralittoral fringe consisting primarily of Rhodophyta, ranging from about MIW to $-38 \mathrm{~cm}$; a midlittoral region composed mainly of Cyanophyta and Chlorophyta, occurring from about $\mathrm{MLW}$ to $+74 \mathrm{~cm}$; and a supralittoral fringe, from +74 to $+122 \mathrm{~cm}$, having the Cyanophyta, Calothrix crustacea, as its sole occupant. 
SUMMARY

1. During the months from January to June, 1967, collections of marine algae were made from aged wooden pilings at Gloucester Point, Virginia. Sampling was directed toward qualitative analysis of the vertical distribution of benthic marine flora.

2. Twenty-six species of benthic marine algae were collected. Of these, there were seven Cyanophyta, eight Rhodophyta, ten Chlorophyta and one Phaeophyte. Except for Bangia fuscopurpurea and Porphyra umbilicalis no Rhodophyta were found above MLW. All Chlorophyta except Bryopsis plumosa, Enteromorpha compressa and E. minima, al1 Cyanophyta and the Phaeophyte (Ectocarpus confervoides) were distributed above MLW to varying heights.

3. Eight species were confined to below MLW in a zone comparable to the infralittoral fringe of $T$. A. Stephenson and $A$. Stephenson. There were six Rhodophyta (Dasya pedicellata, Polysiphonia denudata, $\underline{P} \cdot \underline{\text { nigrescens }}$, Ceramium rubrum, $\underline{\text { r strictum, Callithamnion }}$ byssoides) and three Chlorophyta (Enteromorpha compressa, E. minima and Bryopsis plumosa).

4. The midlittoral region may be divided into seven floral levels based on uppermost range extensions of 16 species: six Cyanophyta, one Rhodophyte, eight Chlorophyta and one Phaeophyte. (i) Monostroma leptodermum and Enteromorpha erecta ranged to a height of 10 to $14 \mathrm{~cm}$ above MLW. (ii) Spirulina subsalsa and Ectocarpus confer- 
voides were found up to $26 \mathrm{~cm}$ above MLW. (iii) Ulothrix flacca, Ulva lactuca and Enteromorpha intestinalis comprised the level attaining a height of about 38 to $44 \mathrm{~cm}$ above MLW. (iv) Microcoleus chthonoplastes, Enteromorpha prolifera and Porphyrosiphon notarisii were found as high as 50 to $54 \mathrm{~cm}$ above MLW. (v) Porphyra umbilicalis, Enteromorpha linza and Microcoleus lyngbyaceus attained a height of 62 to $66 \mathrm{~cm}$ above MLW. (vi) Bangia fuscopurpurea formed a band at about $66 \mathrm{~cm}$ above MLW. (vii) Entophysalis deusta and Schizothrix calcicola ranged upwards to $74 \mathrm{~cm}$ above MLW.

5. A supralittoral fringe, from about 74 to $122 \mathrm{~cm}$ above MLW, was occupled exlusively by the Cyanophyte, Calothrix crustacea. 6. Collections from acrylic plastic substrata did not reveal the presence of algae until May. Species setting on the colonization substrata collected June 1 were entirely different from those found in the June 30 collection indicating a seasonal change in the flora. Between the June 1 and June 30 collections from succession substrata there was a continued development of two species, colonization of five spectes and disappearance of three species.

7. Six species are reported here for the first time from Virginia: Ectocarpus confervoides, Enteromorpha compressa, Enteromorpha erecta, Enteromorpha prolifera, Monostroma leptodermum and Ulothrix flacca. 
APPENDIX 
APPENDIX A

SPEC IES COLLECTED

\section{Cyanophyta}

Calothrix crustacea Schousboe et Thuret ex Bornet et Thuret Entophysalis deusta (Meneghini) Drouet \& Daily Microcoleus chthonoplastes (Mertens) Zanardini ex Gomont Microcoleus 1yngbyaceus (Kützing) Crouan Porphyrosiphon notarisil (Meneghini) Kutzing Schizothrix calcicola (C. Agardh) Gomont Spirulina subsalsa Oersted ex Gomont

Rhodophyta

Bangia fuscopurpurea (Di11wyn) Lyngbye Callithamnion byssoides Arnott Ceramium rubrum (Hudson) C. Agardh Ceramium strictum (Kützing) Harvey Dasya pedicellata (C. Agardh) C. Agardh Polysiphonia denudata (Dillwyn) Kützing Polysiphonia nigrescens (Hudson) Greville Porphyra umbilicalis (Linnaeus) J. Agardh

Phaeophyta

Ectocarpus confervoides (Roth) Le Jolis

\section{Chlorophyta}

Bryopsis plumosa (Hudson) C. Agardh Enteromorpha compressa (Linnaeus) Greville Enteromorpha erecta (Lyngbye) J. Agardh Enteromorpha intestinalis (Linnaeus) Link Enteromorpha linza (Linnaeus) J. Agardh Enteromorpha minima Nageli Enteromorpha prolifera (Müller) J. Agardh Monostroma leptodermum Kjellman Ulothrix flacca (Dillwyn) Thuret Ulva lactuca Linnaeus 


\section{APPENDIX B}

MONTHLY SUMMARY OF MEAN LOWS, MEAN HIGHS AND MEANS FOR WATER TEMPERATURE AND AIR TEMPERATURE

\begin{tabular}{|c|c|c|c|c|c|c|}
\hline \multirow[b]{2}{*}{ MONTH } & \multicolumn{2}{|c|}{ Water Temp. } & $(\infty)$ & \multicolumn{3}{|c|}{ Alr Temp. $\left({ }^{\circ} \mathrm{C}\right)$} \\
\hline & LOW & HIGH & MEAN & LOW & HIGH & MEAN \\
\hline January & 4.3 & 5.4 & 4.7 & 2.1 & 10.3 & 6.1 \\
\hline February & 4.0 & 5.2 & 4.5 & -0.5 & 7.8 & 3.8 \\
\hline March & 6.2 & 8.2 & 6.7 & 4.2 & 14.5 & 8.5 \\
\hline April & 11.2 & 13.4 & 12.1 & 10.1 & 21.4 & 15.1 \\
\hline May & 15.0 & 16.8 & 15.7 & $12 \cdot 3$ & 22.0 & 16.3 \\
\hline June & 21.3 & 23.9 & 22.4 & 20.3 & 28.7 & 24.6 \\
\hline
\end{tabular}




\section{LITERATURE CITED}

Bieb1, R. 1962. Seaweeds, p. 799-816. In R. A. Lewin (ed.) Physiology and Biochemistry of Algae. Academic Press, N. Y. Colman, John. 1933. The nature of intertidal zonation of plants and animals'. J. Mar. Biol. Ass. U. K. 18:435-476.

Doty, Maxwell S. 1946. Critical tide factors that are correlated with the vertical distribution of marine algae and other organisms alongthe Pacific coast. Eco1. 27:315-328.

Doty, Maxwell S. 1957. Rocky intertidal surfaces, p. 315-328. In J. Hedgpeth (ed.) Treatise on marine ecology and paleoecology, I. Geol. Soc. Amer., Mem. 67.

Drouet, Francis. 1962. Gomont's ecophenes of the blue-green alga, Microcoleus vaginatus. Proc. Acad. Nat. Sci. Phila. 114: 191-205 .

Drouet, Francis. 1963. Ecophenes of Schizothrix calcicola (Oscillatoriaceae). Proc. Acad. Nat. Sci. Phila. 115:191-281. Drouet, Francis. 1964. Ecophenes of Microcoleus chthonoplastes. Rev. Algol. 7:315-324.

Drouet, Francis and William A. Daily. 1956. Revision of the coccoid Myxophyceae. Butler Univ. Bot. Stud. 12:1-218.

Earle, Linda C. and Harold J. Humn. 1964. Intertidal zonation of algae in Beaufort Harbor. J. Elisha Mitchell Sci. Soc. 80: $78-82$ 
Jaccard, P. 1902. Louis de distribution florale dans la zone alpine. Bul1. Soc. Vaudoise Sci. Nat. 38:69-130.

Johnson, D. S. and A. F. Skutch. 1928. Littoral vegetation on a headland of Mt. Desert Island, Maine, I. Submersible or strictly 1ittoral vegetation. Ecol. 9:188-215.

Kingsbury, John M. 1962. The effect of waves on the composition of a population of attached marine algae. Bull. Torr. Bot. Club $89: 143-160$.

Lewis, J.R. 1964. The ecology of rocky shores. The English Universities Press Ltd., London. 323p.

Southward, A. J. 1958. The zonation of plants and animals on rocky sea shores. Biol. Rev. 33:137-177.

Southward, A. J. and J. H. Orton. 1954. The effects of wave-action on the distribution and numbers of the commoner plants and animals living on the Plymouth breakwater. J. Mar. Biol. Ass. U. K. $33: 1-19$.

Stephenson, T. A. and A. Stephenson. 1949. The universal features of zonation between tide-marks on rocky coasts. J. Ecol. 37: 289-305

Stephenson, T. A. and A. Stephenson. 1950. Life between tide-marks in North America. I. The Florida Keys. J. Ecol. 38:354-402. Stephenson, T. A. and A. Stephenson. 1952. Life between tide-marks in North America. II. Northern Florida and the Carolinas. J. Ecol. $40: 1-49$

Stephenson, T. A. and A. Stephenson. 1954. Life between tide-marks in North America. III. Nova Scotia and Prince Edward Island. J. Ecol. 42:14-70. 
Taylor, William Randolph. 1957. Marine algae of the northeastern coast of North America. 2d ed. Univ. Mich. Press, Ann Arbor. 509p.

Taylor, William Randolph. 1960. Marine algae of the eastern tropical and subtropical coasts of the Americas. Univ. Mich Press, Ann Arbor. 870 p.

Womersley, H. B. S. and S. J. Edmonds. 1952. Marine coasta1 zonation in southern Australia in relation to a general scheme of classification. J. Eco1. 40:84-90.

Zaneveld, Jacques S. 1966a. The marine algae of the American coast between Cape May, N. J., and Oape Hatteras, N. C. I. The Cyanophyta. Bot. Mar. 9:101-128.

Zaneveld, Jacques S. 1966b. The benthic marine algae of Delaware: A preliminary checklist. Scientific series, Pub1. No. 2. Old Dominion College, Norfold, Va. $35 p$.

Zaneveld, Jacques S. and William D. Barnes. 1965. Reproductive periodicities of some benthic algae in lower Chesapeake Bay. Ches. Sci. 6:17-32. 
VITA

\section{Barry Lee Wulff}

Born in Mt. Kisco, New York, 17 February, 1940. Graduated from Kents Hill School, Kents Hill, Maine, June 1958. Entered U. S. Army, July 1958 and served as a Radar Repairman at South Park

Military Reservation, Pittsburgh, Pennsylvania. B. S. (Blology)

State University of New York, Cortland, New York, June 1965.

Entered School of Marine Sclence (Virginia Institute of Marine

Science) of the College of William and Mary, June 1965; graduate assistantship in the Department of Environmental-Physiology,

September 1965 to present. 